\title{
Societal Implications of Forest and Water Body Area Evolution in Czechia and Selected Regions
}

\author{
Diana Carolina Huertas Bernal ${ }^{1, *}{ }^{\oplus}$, Ratna Chrismiari Purwestri ${ }^{1}{ }^{1}$, Mayang Christy Perdana ${ }^{2}$, Miroslav Hájek ${ }^{1}$, \\ Meryem Tahri ${ }^{1}{ }^{\mathbb{D}}$, Petra Palátová ${ }^{1}$ [D and Miroslava Hochmalová ${ }^{1}$ (i)
}

1 Faculty Forestry and Wood Sciences, Czech University of Life Sciences Prague, Kamýcká 129, 16500 Praha-Suchdol, Czech Republic; purwestri@fld.czu.cz (R.C.P.); hajek@fld.czu.cz (M.H.); tahri@fld.czu.cz (M.T.); palatovap@fld.czu.cz (P.P.); sodkova@fld.czu.cz (M.H.)

2 Faculty of Environmental Sciences, Czech University of Life Sciences Prague, Kamýcká 129, 16500 Praha-Suchdol, Czech Republic; perdana@fzp.czu.cz

* Correspondence: huertas-bernal@fld.czu.cz; Tel.: +420-773-225-794

\section{check for}

updates

Citation: Huertas Bernal, D.C.

Purwestri, R.C.; Perdana, M.C.; Hájek,

M.; Tahri, M.; Palátová, P.;

Hochmalová, M. Societal Implications

of Forest and Water Body Area

Evolution in Czechia and Selected

Regions. Remote Sens. 2021, 13, 4019.

https://doi.org/10.3390/

rs13194019

Academic Editor: Sudhanshu

Sekhar Panda

Received: 30 August 2021

Accepted: 5 October 2021

Published: 8 October 2021

Publisher's Note: MDPI stays neutral with regard to jurisdictional claims in published maps and institutional affiliations.

Copyright: (c) 2021 by the authors. Licensee MDPI, Basel, Switzerland. This article is an open access article distributed under the terms and conditions of the Creative Commons Attribution (CC BY) license (https:/ / creativecommons.org/licenses/by/ $4.0 /)$.
Abstract: Land cover evolution is an environmental factor that can be used to characterize forest ecosystem services (FES). This study aims to analyze the change in forest cover and water bodies between 1990 and 2018 in the whole Czech Republic, and in the Central Bohemian and South Moravian regions, and its effects on freshwater provision. Additionally, we attempt to understand the societal implications of water quality, public perception, and environmental investment on natural ecosystems. Forest cover and water body data were obtained from the Corine land cover database, while water quality and investment were compiled from the Czech Statistical Office. Public perceptions on the Czech FES were collected from a national survey. Between 1990 and 2018, forest cover has increased by $3.94 \%$ and water bodies by 7.65\%; however, from 2014 to 2018 , severe droughts were reported that compromised the availability of surface water, presumably on artificial structures, causing an increase in the occupied area. Regarding public perception, respondents with less education, and the older population, obtained an assessment of the low performance of the FES, while the water quality and investment indicate that environmental funding has contributed to improving the quality of outflow water from the wastewater treatment plants, fulfilling all the allowed limits of the urban wastewater treatment directive. Hence, a multidisciplinary approach can help decision makers promote policies that integrate environmental management measures, investment protection, and contribute to sustainable development.

Keywords: ecosystem services; water quality; land cover change; policy instruments; public perception

\section{Introduction}

Ecosystem services are the benefits that humans obtain from functional ecosystems [1,2], with water provision being among the essential roles of forest ecosystem services (FES) [3,4], while trees are expected to protect and provide clean drinking water [5-7]. For human wellbeing, the role of water stretches from consumption to essential recreation elements [8,9]. Since the early 1990s, ecosystem services have been extensively studied to understand interactions and pressures that affect them $[6,10]$, while evaluating the FES has become essential information to policymakers [11]. Ecosystems related to water have been studied by analyzing inland and marine waters, and are classified as hydrologic ecosystem services [12]. Some studies have reported that the results of the perception and evaluation of water, for instance, the optics and perception of water quality towards pollution and aesthetics [13,14], create an evaluation and verbal description of water landscape [9], and of the perception of drinking water quality [15-17].

Furthermore, land cover is defined as the bio- or physical cover on the surface of the Earth, which is categorized into different land classes, e.g., grassland, forest area, etc. [18-20]. The water body is one of these categories. It can be of temporary or permanent 
nature [21]. In climate change, land cover is considered to be one of the factors of the essential climate variables (ECV) [22], which are used to characterize, value, and study environmental phenomena [23-25]. Its monitoring allows the quantification of the carbon sinks, release of greenhouse gas (GHG) and other substances emissions, the increase in air temperature globally, gains or losses in forest extension, loss of biodiversity, and allows the identification of the trends changing land and water resources [26-31]. Land cover is changing due to a conversion in land use, natural conditions, or land management over time $[20,25,32]$, and each land cover classification gain and loss can be calculated [25,33]. As a result of the land cover change, the increase in extreme events, and the disturbances in the ecosystems, due to climate change, forests are affected, which results in disturbances in water supply and regulation [3,4,34-36].

On the other hand, water quality has implications for human and ecosystem health [37-39]; for example, wastewater treatment is developed principally as a solution to upgrade the water quality status, which is more feasible than discharging the wastewater into the environment, and to the lower ecological risks, especially for hydrosphere deterioration [40,41], such as organic pollution and eutrophication [42,43]. Water quality analysis identifies the effectiveness of certain wastewater treatment processes [44,45]. In the Czech Republic, agriculture and communities are among the most polluting activities that deteriorate the surface water quality [46-48], due to continuous discharges affecting the maximum retention capacity, causing a slow elimination of pollutants [49]. Additionally, the environmentally motivated subsidies, as an environmental investment in wastewater management, provide information about strategies on prevention, reduction, and elimination of water pollution, and can be used as one of the components to evaluate the hydrological ecosystem services [6]. Community perception does not always agree with the scientific views, but it provides information on the level of understanding and firsthand experience on the topic. Several studies that linked the quantitative results of the land cover and water body changes, and the community perception, revealed the importance of the community in supporting environmental protection, in particular, the forests and watershed preservation [50-52].

Several studies have been carried out worldwide, including Czechia, on changes in land cover [24,53-57], ecosystem services [2,12,58-64], water quality [13,40,46-49,65-67], economic instruments [68-71], and assessments of diverse factors that influence the provision of ecosystem services $[30,31,34,35,65,72-75]$; however, there are still knowledge gaps in the study of social, environmental, and economic interactions that may affect the ecological status of ecosystem services. Ensuring a sufficient level of hydrological ecosystem services that meet the needs of society is one of the significant challenges currently being faced [6]. To answer the research questions on what factors affect the services of hydrological ecosystems, and how they manifest and evolve their effect over time, it is necessary to evaluate different aspects of water resources, such as availability, quality, management measures, environmental policies, and, in general, all the pressures that may affect them. Therefore, understanding the implications of land cover change, water quality, environmental investment, and public perception of hydrological ecosystem services can help identify how to improve resource management.

The first objective of this article is to evaluate the incidence of forest cover change at the level of hydrological ecosystem services in Czechia, and, specifically, in the Central Bohemian and South Moravian regions. The second is to identify the societal implications by investigating the interactions between perception and the level of performance, wastewater treatments, economic instruments, and the evolution of FES. The results provide information that can be used by decision makers to promote management measures, investment, and spending, in accordance with the needs of FES and the perception of the Czech public. The methodology can be replicated in other regions with other ecosystem service components for a better understanding of the dynamics that develop within natural ecosystems. 


\section{Methods}

\subsection{Study Area}

This case study was carried out in the Czech Republic (Czechia) and selected regions within the country. Czechia is located in the central part of Europe, between latitudes $48^{\circ}$ and $51^{\circ} \mathrm{N}$ and longitudes $12^{\circ}$ and $19^{\circ} \mathrm{E}$, in the temperate zone of the Northern Hemisphere with an area of $78,870 \mathrm{~km}^{2}$, a population of 10,693,939, and is divided into 14 regions [76], of which the following two are part of the study: Central Bohemian (Středočeský kraj), and South Moravian (Jihomoravský kraj), see Figure 1.

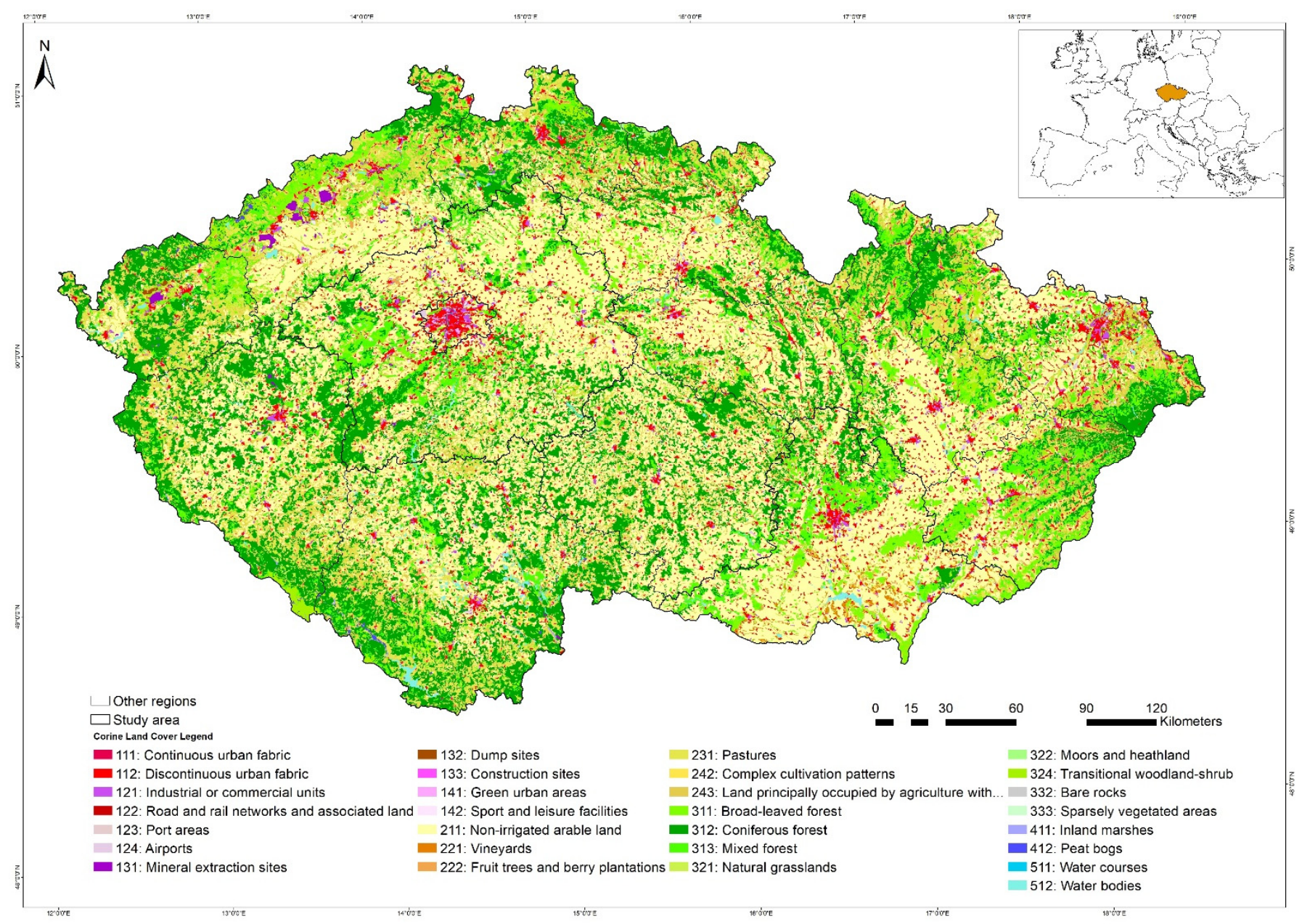

Figure 1. Location of the study area and the CLC categories in 2018.

The Central Bohemian region is the largest region of Czechia and is in the central part of the historical region of Bohemia. It has an area of 10,928 $\mathrm{km}^{2}$ and 1,385,141 inhabitants [76]. The main sources of water pollution are industry, agriculture, and pollution from small municipalities, which lack sewer connections and wastewater treatment plants (WWTPs). In 2018, agricultural land occupied $60.2 \%$ of the territory of the region, forest land $27.5 \%$, and surface water $1.9 \%$. Since 2000 , the conversion of arable land into permanent pasture has been reported in built-up areas and courtyards [77].

The South Moravian region reports 1,191,989 inhabitants in an area of $7188 \mathrm{~km}^{2}$ [76]. In 2018, water quality was reported as polluted to very heavily polluted, due to intensive agricultural management and the textile industry. Agricultural land occupies $58.8 \%$ of the region, forests $28.1 \%$, and water areas $2.2 \%$. Since 2005 , the cultivated area of agricultural land has decreased and the area of permanent pasture has increased for green urban areas, industrial or commercial units, and mining areas [78]. 


\subsection{Data Selection, Acquisition and Preprocessing}

The selection of factors that affect the hydrological ecosystem services in the Czech Republic was carried out considering the conditions of the study area and the availability of reliable information, to have enough data to allow the variables to be correlated to identify patterns or trends. National reports on the state of the water resource were searched, finding interesting topics to compare their behavior, such as floods, droughts, and water quality; however, when incorporating other comparison factors such as environmental investment and public perception to make the analysis more meaningful, incompatibilities were identified to correlate variables such as the period of events in the case of floods and droughts. In this way, the quality of water and environmental investment in the WWTPs, to compare their operation with the perception of the public and their connection with the evolution of plant cover, were the most relevant.

To answer the objectives of the paper, research data were collected from different sources. Forest cover and water body evolution data were collected from the Corine land cover (CLC) database. For the societal implication indicators, water quality, instruments on water pollution abatement and control, and the public perception and evaluation on the Czech forest water provisioning services were compiled from different sources, as can be seen in Figure 2.

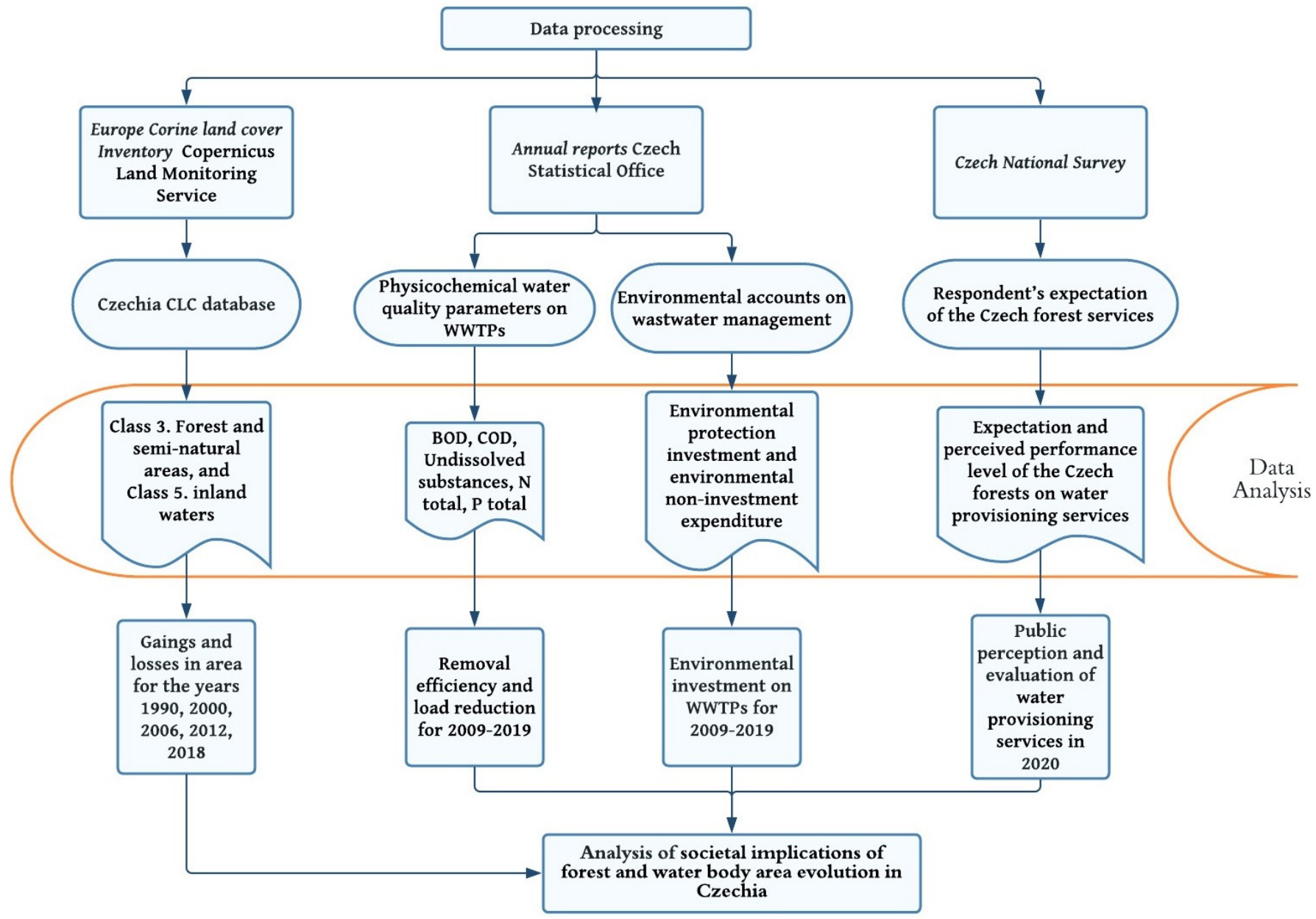

Figure 2. Data processing.

\subsubsection{Forest Cover and Water Bodies}

The land cover of Czechia (in ha) was extracted from the Corine land cover (CLC) database from the Copernicus Land Monitoring Service [79] and processed with ArcGIS Desktop version 10.8 [80]. The database was developed by interpreting satellite images, 
Landsat, SPOT, IRS P6 LISS, RapidEye, and Sentinel-2; each inventory and update was developed according to the technology and information available in the elaboration period. The CLC database contains an inventory and four updates from the years 1990, 2000, 2006, 2012 and 2018. It has evolved according to the progress in the instruments and methods of interpretation and image processing, with a scale of 1: 100,000 and a minimum mapping unit (MMU) of 25 hectares, the geometric precision of 1990 is $\leq 50 \mathrm{~m}$, while for 2000, 2006 and 2012 it is $\leq 25 \mathrm{~m}$ and for 2018 it is $\leq 10 \mathrm{~m}$ with the Sentinel-2 satellite data. It is a free access product that offers to monitor land cover over time to have reliable information about the phenomena that occur on Earth [81]. For further information on the methodology and instructions for use, please consult the following link: https://land.copernicus.eu/ user-corner/technical-library / clc-product-user-manual/view (accessed on 1 June 2021).

The CLC database includes the following five categories: (1) artificial surfaces; (2) agricultural areas; (3) forest and semi-natural areas; (4) wetlands; and (5) water bodies and 44 classes of land cover. The CLC in Czechia consists of 29 classes (Figure 1). Categories of forest and semi-natural areas, and inland waters are further described in Table 1. The forest areas from the CLC analyzed in this paper were under the category of broad-leaved, coniferous, and mixed forests, which were compared to the information collected from the Ministry of Agriculture (MoA) of the Czech Republic [82,83]. Meanwhile, water body data were compiled from the watercourses and water bodies of the CLC, which were compared with the national reports collected from the yearbooks of Czech Statistical Office Section 3.1 land use or land use balance every six years from 2000 to 2018 [84]. This was due to the fact that annual reports on water resource management do not contain information about surface area occupied by water bodies. The earliest national forestry report was in 1998 and 2000 for the water body land balance, so in this paper, the year 1990 was not included in the comparison analysis of the CLC and the national reports, while the area analysis included the periods reported by the CLC.

\subsubsection{Water Quality}

Raw data of physicochemical water quality parameters, i.e., biological oxygen demand (BOD), chemical oxygen demand (COD), undissolved substances, nitrogen totals ( $\mathrm{N}$ total), phosphorus totals ( $\mathrm{P}$ total), and wastewater treatment plants characteristics, in the period of 2009-2019 were extracted from the annual reports of the Czech Statistical Office on water supply systems, sewerage and watercourses [84]. The units of the measured parameters for both inflow and outflow wastewater treatment plants are expressed in tons/year. The raw data indicate the analysis method for biological oxygen demand using a standard incubation test period of 5 days at $20^{\circ} \mathrm{C}$ and chemical oxygen demand using the dichromate method.

Removal efficiency (RE) or load reduction among parameters was also compared based on the required minimum threshold level of load reduction suggested by the urban wastewater treatment directive (UWWTD) $[85,86]$.

\subsubsection{Instruments on Water Pollution Abatement and Control}

Economic instruments (EIs) are designed to achieve environmentally sustainable objectives [87] using economic or market incentives to generate desired behavior between both producers and consumers [88]. Since there are several classifications of EIs, this research used the categories proposed by the Organisation for Economic Co-operation and Development (OECD) [89]. In the Czech Republic, there are a wide series of instruments reported to address water pollution, such as (1) taxes for permitted discharge of wastewater into groundwater, or surface water; (2) subsidies supporting de-sludging of ponds, flood damage mitigation, environmental education, and enlightenment; and (3) voluntary approaches such as eco-labeling system, EMAS - eco-management and audit scheme. This study used the environmentally motivated subsidies in the form of environmental protection expenditure accounts [89] to provide information on the economic resources devoted to the prevention, reduction, and elimination of water pollution [90] in order to compare 
the investment with the quality of the water in the wastewater treatment plants. In 2019, more than CZK 10.7 billion was invested in support for water management [91].

Table 1. Summary of the CLC of forest and semi-natural areas in the Czech Republic, modify from CLC Nomenclature [21].

\begin{tabular}{ccc}
\hline & Classification & Definition \\
\hline $\begin{array}{c}\text { Forest and } \\
\text { semi-natural areas }\end{array}$ & Forests & Broad-leaved forest * \\
& & $\begin{array}{c}\text { Areas occupied by forests and woodlands with } \\
\text { trees higher than } 5 \text { m and canopy closure of a } \\
\text { minimum of } 30 \% \text { or young shoots with the } \\
\text { minimum cut-off-point of } 500 \text { subjects per ha. } \\
\text { Vegetation formation predominated by } \\
\text { broad-leaved species. }\end{array}$ \\
\hline
\end{tabular}

Areas occupied by forests and woodlands with trees higher than $5 \mathrm{~m}$ and canopy closure of a

Forests Coniferous forest * minimum of $30 \%$, or young shoots with the minimum cut-off-point of 500 subjects per ha.

Vegetation formation predominated by coniferous species.

Areas occupied by forests and woodlands with trees higher than $5 \mathrm{~m}$ and canopy closure of a Forests Mixed forest * minimum of $30 \%$, or young shoots with the minimum cut-off-point of 500 subjects per ha.

Vegetation formation is neither broad-leaved nor coniferous species predominate.

\begin{tabular}{|c|c|c|c|}
\hline & $\begin{array}{l}\text { Scrub and/or } \\
\text { herbaceous vegetation } \\
\text { associations }\end{array}$ & Natural grasslands & $\begin{array}{l}\text { Grasslands under no or moderate human } \\
\text { intervention. }\end{array}$ \\
\hline & $\begin{array}{l}\text { Scrub and/or } \\
\text { herbaceous vegetation } \\
\text { associations }\end{array}$ & Moors and heathland & $\begin{array}{l}\text { Low and closed cover vegetation is dominated by } \\
\text { bushes, shrubs, dwarf shrubs, and herbaceous } \\
\text { plants, which form a summit stage. }\end{array}$ \\
\hline & $\begin{array}{l}\text { Scrub and /or } \\
\text { herbaceous vegetation } \\
\text { associations }\end{array}$ & $\begin{array}{c}\text { Transitional } \\
\text { woodland-shrub }\end{array}$ & $\begin{array}{l}\text { Transitional bushy and herbaceous vegetation } \\
\text { with occasional scattered trees; hence, can } \\
\text { correspond to woodland degradation, forest } \\
\text { regeneration, or natural succession. }\end{array}$ \\
\hline & $\begin{array}{l}\text { Open spaces with little } \\
\text { or no vegetation }\end{array}$ & Bare rocks & $\begin{array}{l}\text { Scree, cliffs, rock outcropping that incorporate } \\
\text { areas of active erosion, rocks, and reef flats above } \\
\text { the high-water mark, inland salt planes. }\end{array}$ \\
\hline & $\begin{array}{l}\text { Open spaces with little } \\
\text { or no vegetation }\end{array}$ & Sparsely vegetated areas & $\begin{array}{l}\text { Areas with scarce vegetation (covering } 10-50 \% \text { of } \\
\text { the surface). }\end{array}$ \\
\hline \multirow[t]{2}{*}{ Water bodies } & Inland waters & Watercourses * & $\begin{array}{l}\text { Natural or artificial watercourses serving as water } \\
\text { drainage channels with a minimum width of } 100 \\
\mathrm{~m} \text {. }\end{array}$ \\
\hline & Inland waters & Water bodies * & $\begin{array}{l}\text { Natural or artificial water bodies are characterized } \\
\text { by the presence of standing water bodies during } \\
\text { most of the year. }\end{array}$ \\
\hline
\end{tabular}

${ }^{*}$ Included categories into the study.

According to the methodology of environmental accounts, environmental protection investment refers to expenses for the acquisition of assets for environmental protection and expenses related to environmental protection activities; while environmental noninvestment expenditure refers to operational activities including wage costs, rent payments, energy, and other materials, supplies, and payments for services of the companies that manage the activities. The wastewater management budget includes the construction of water treatment plants and sewerage systems to control water quality and other activities and facilities the prevention of pollution generation [92]. 
Environmental protection investment and environmental non-investment expenditure of Czechia, in CZK thousands current prices, with inflation, average exchange rate in 2019: EUR 1 = CZK 25.36 [92], on wastewater management for the period of 2005-2019, were collected from the annual reports of the Czech Statistical Office on environmental accounts [93].

\subsubsection{Public Perception}

Forest perception is any opinions or thoughts about the features of FES in water provisioning [5]. The performance in this paper is defined as the respondent's perceived level of the selected forest products or services based on their knowledge and experiences [94].

A computer-assisted web interviewing (CAWI) technique in November 2020 was performed in collaboration with an external market research company, STEM/MARK, a.s. (Prague, Czech Republic). The recruitment was performed by sending the questionnaires to the potential respondents on the company's list based on age, sex, education level, region, and village size (total recruited respondents aged 16 to 65 years $(\mathrm{N}=1509)$ in the whole Czech Republic). All returned questionnaires were included in the analysis (100\%). The questionnaire was designed as a closed-ended tool. The four degrees of the respondent's expectations of the Czech forest services related to provision and regulation of water were used, from one ( 1 = strongly disagree) to four $(4=$ strongly agree). One category was added for those who could not judge. Five degrees of scores, whereby 1 (one) was not very important and 5 (five) was very important, were applied for the perceived performance level of the Czech forest services related to the provision of water. The education levels of the respondents were categorized as a high school graduate without the secondary school leaving certificate (maturita), or with the certificate and higher education (university level).

\subsubsection{Data Analysis}

The CLC was processed by clipping the land cover layers with the region layer of the Czech Republic downloaded from the Nomenclature of Territorial Units for Statistics (NUTS) 2021 [95]. Afterwards, the spatial joint and the area calculation of the different coverage areas present in the Czech Republic were used, then the attributes of the tables were exported to Excel and finally, the graphical outputs of land cover location, losses and gains were generated.

Distribution of the non-categorical data was first tested for normality using the Kolmogorov-Smirnov test. The forest land and water bodies in Czechia were presented in mean and standard deviation. Pairwise comparisons in the observed years (1990, 2000, 2006, 2012, and 2018) were analyzed using the Wilcoxon signed-rank nonparametric test (for non-categorical and not normally distributed data). Similarly, the forest and water body area changes were analyzed using the Wilcoxon signed-rank test for the years 1990-2006, 2006-2018, and 1990-2018.

Gain, losses, the rate of forest area, and water body change $[33,96]$ were calculated using the following Formula (1):

$$
\text { percentage of area change }=\frac{\text { area }(b)-\operatorname{area}(a)}{\text { area }(b)} \times 100 \%,
$$

where area (a) was the forested landscape and water bodies (in ha) at the earliest reported year in the paper (1990), while area (b) referred to the final year (2018).

Removal efficiency or load reduction [41,97] for each of the water quality parameters measured per year was calculated using the following Formula (2):

$$
R E \text { or Load reduction }(\%)=\frac{\text { Inflow }- \text { Outflow }}{\text { Influent }} \times 100 \text {, }
$$


The comparison between environmental protection investment, environmental noninvestment expenditure, and water pollution removal efficiency was analyzed using Spearman's nonparametric correlation for the period 2005-2019.

For comparing means of the age of respondents (non-categorical and normally distributed data) between regions, the data were analyzed using ANOVA, while a chi-square test was used to analyze the categorical data (gender of the respondents, education level, city size, and frequency of forest visit). Binary logistic regression was applied to define the significant predictors of the public expectations, and the perceived performance level of the Czech FES related to the provision of freshwater ( $1=$ low score of public expectation/perceived performance level). The variables included in the analysis were age, sex ( 1 = female), education level ( 1 = maturita and higher), frequency of forest visit ( 1 = rarely, twice a year, and less), size of the city, and region.

The statistical significance in all analyses was designated as a $p$-value of less than 0.05. Statistical analysis was performed using IBM SPSS Statistics version 25 (IBM Corp., Armonk, NY, USA).

\section{Results}

\subsection{Forest Cover and Water Bodies Area at National Level}

The forested landscape of the country occupies about $33.7 \%$ of the country's total area. From the national report in 2018, the forests consisted of $71.5 \%$ coniferous and $27.3 \%$ broad-leaved trees, respectively, and about $1.2 \%$ was forest land without trees. Of the total coniferous trees, Norway spruce (Picea abies) accounted for $50.0 \%$, followed by $16.2 \%$ pine, beech $(8.6 \%)$, oak (7.3\%), birch (2.8\%), and others (8.7\%) [98]. Of the total Czech forested area, $75 \%$ was dedicated to the production forests $[99,100]$. Additionally, more than $50 \%$ of the forests in the country are managed by the state, in which the primary direction of the management (more than 90\%) is as a forest-based enterprise [98]. From the CLC, high forest cover was found in South and Central Bohemia, followed by the Plzeň region.

More than half of the area of Czech forests are owned by the state (54.09\%). As many as $19.27 \%$ of the forests are owned by individual forest owners, followed by municipal and urban forests $(17.17 \%)$, church and other religious organizations (5\%), legal entities $(3.27 \%)$, and cooperative and associations (1.19\%). Furthermore, the rest of the land (0.01\%) is other types of forest ownership. The majority share of the state ownership is managed by the Forests of the Czech Republic (state forestry company), and there are also other organizations. Therefore, organizations established by the state have a significant impact on the forest management implementation that is related to the total forest land in the country [101]. Given that the state can pursue uniform management goals, while the goals of the same groups of owners may be different, and due to their share in the ownership structure, they have less opportunity to influence the state forestry policy.

The Czech hydrological system consists of the following three main watersheds: the basins of the Elbe, the Odra, and the Morava rivers [102]. In 2018, the water bodies reported by the CLC occupied about $0.74 \%$ of the total area of the country; a high water body area was found in South Bohemia and Central Bohemia, followed by the South Moravian region. For the same year, the national report in the category of surface water bodies reported an area of $2.11 \%$.

Figure 3 depicts the geospatial representation of forest cover and water bodies in Czechia in 1990-2006, 1990-2018, and 2006-2018. The CLC database generated about 1.5\% more forest areas (range: 0.72 to 1.90) in the selected years, as compared to the national report by the Czech MoA. The low proportions of additional areas in the CLC were similar to the forested landscape without trees $[98,103,104]$. The CLC provided information on coniferous, broad-leaved, and mixed-forest regions; notwithstanding, the Czech forestry report only presented the areas of coniferous and broad-leaved forests. 

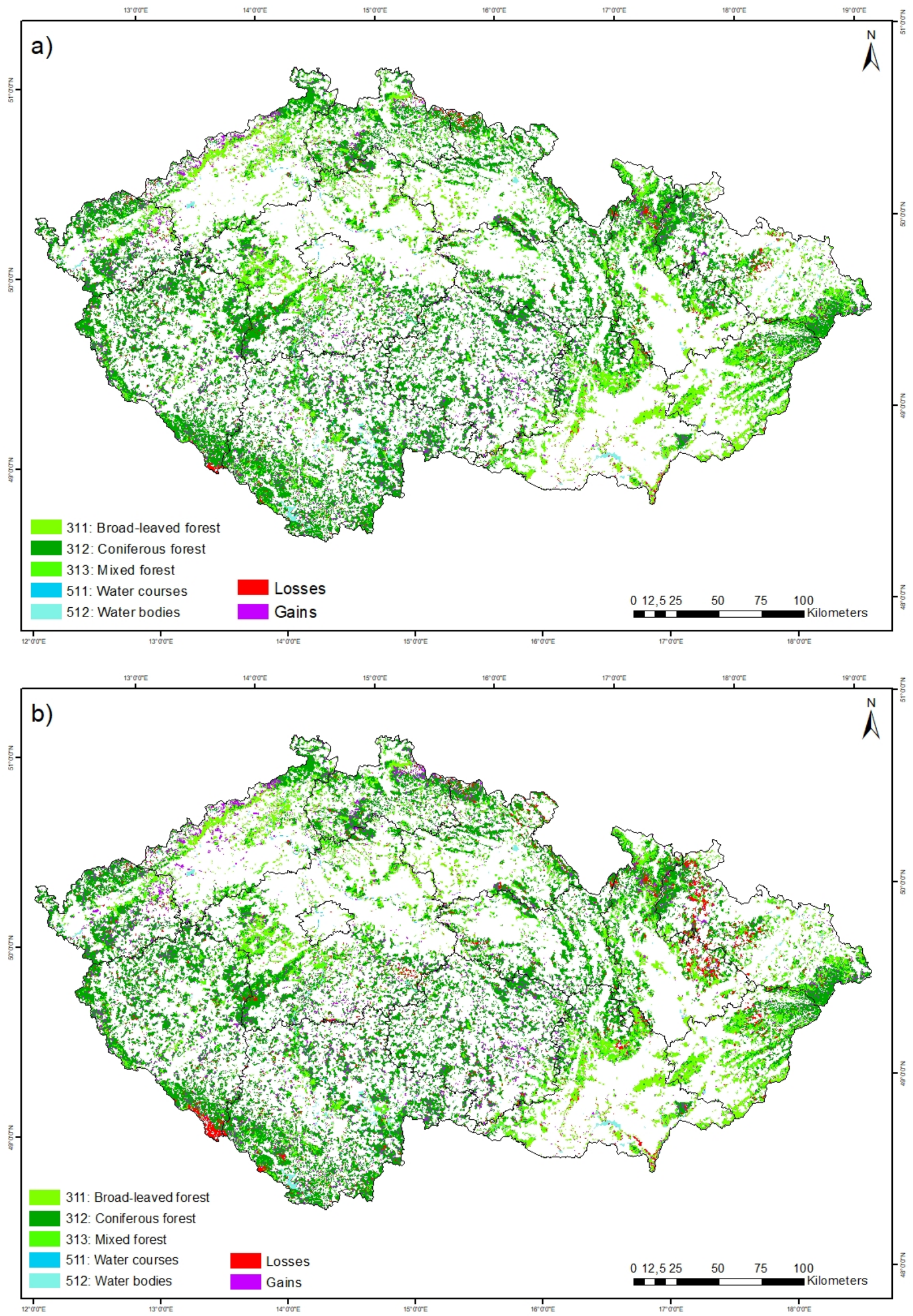

Figure 3. Cont. 


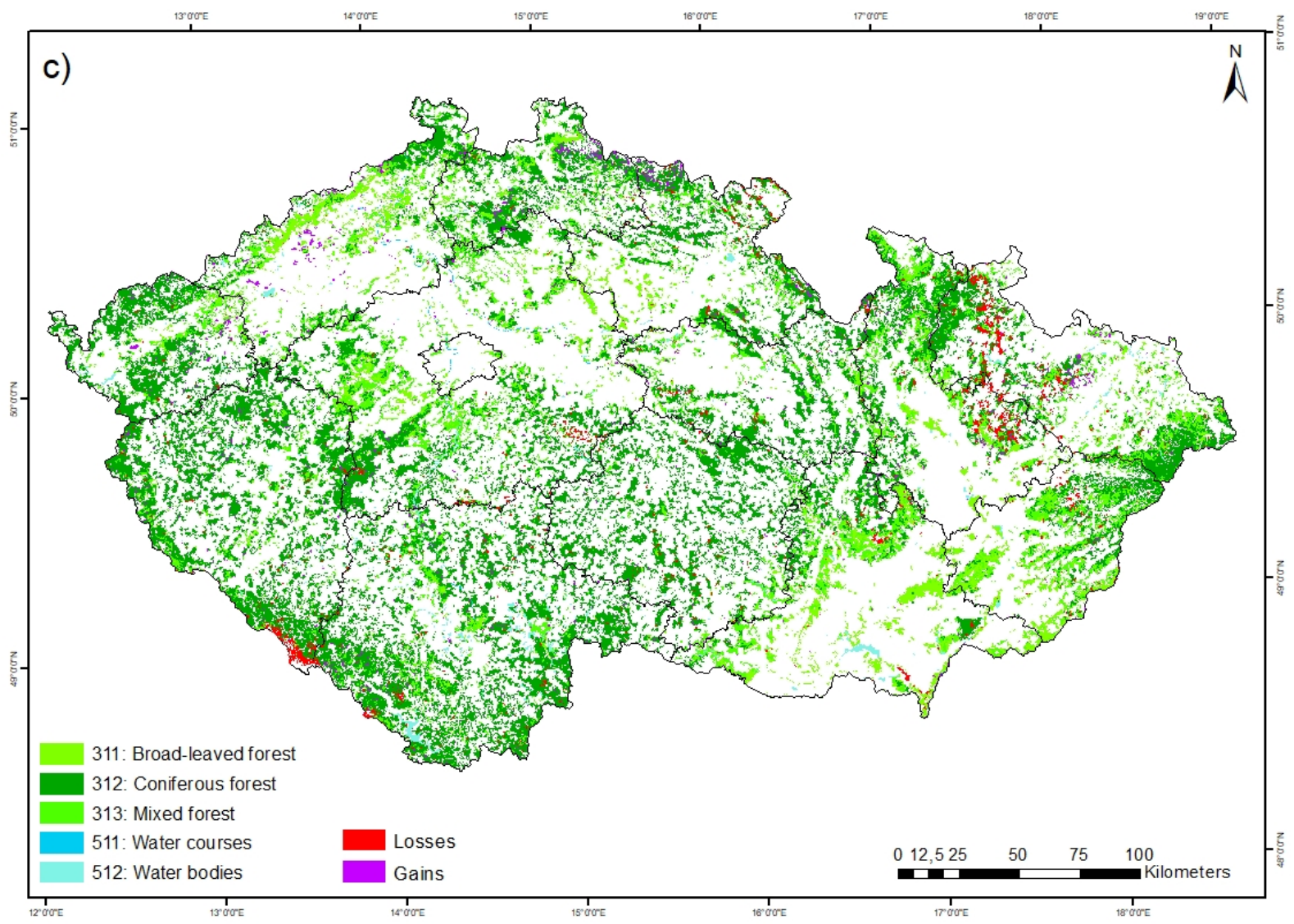

Figure 3. Geospatial representation of forest cover and water body area change in the Czech Republic. (a) 1990-2006; (b) 1990-2018; (c) 2006-2018.

Figure 3 indicates, in red, that to the north in the Liberec and Hradec Králové regions, to the northeast in the Moravian-Silesian and Olomouc regions, and the west in the Plzen region, there was a reduction in the forest cover in the studied areas (coniferous, broad-leaved, and mixed forest), which became transitional woodland-shrubbery, that is, transitional areas with shrubbery or herbaceous vegetation with occasional scattered trees; however, they remain in the category of forest and semi-natural areas. This is consistent with the results of the study conducted in 2018, where, according to the scale resolution (20 m), the land cover analysis identified a reduction in coniferous forests due to disturbances of the bark beetle and the Kyrill windstorm (2007), while deciduous and mixed forests persisted during the study period [105]. At the same time, Figure 3 shows a violet gain area, which occurs in small patches distributed throughout the territory, and, specifically, in the regions of Karlovy Vary, Ústí nad Labem, Liberec, Vysočina, South Bohemia, and Plzeň.

Table 2 shows the Czech forest areas' evolution based on the CLC classification by the type of forest trees. Ordinarily, based on the total forested landscape and the areas by forest type (coniferous, broad-leaved, and mixed forest), significant increases have been observed in 1990, compared to the years 2006, 2012, and 2018. No significant increase in the forest areas was found in the broad-leaved and mixed forests between 1990 and 2018. The coniferous forest area slightly decreased after 2012, and even more in 2018, compared to 2006. 
Table 2. Land cover changes in the Czech Republic in 1990, 2000, 2006, 2012, and 2018 (in ha), by type of forest and inland water, based on the CLC database, processed, and calculated by the authors [79].

\begin{tabular}{|c|c|c|c|c|c|}
\hline \multirow[b]{2}{*}{ Type of Cover } & \multicolumn{5}{|c|}{ Year } \\
\hline & 1990 & 2000 & 2006 & 2012 & 2018 \\
\hline \multicolumn{6}{|c|}{ Forest area } \\
\hline \multicolumn{6}{|l|}{ Central Bohemia } \\
\hline Coniferous forests & $156,729.55^{b, c, d, e}$ & $166,094.78^{a}$ & $167,559.52^{a}$ & $164,229.98^{a}$ & $164,314.22^{a}$ \\
\hline Broad-leaved forests & $31,569.65$ & $34,807.30$ & $34,871.22$ & $35,057.24$ & $35,147.08$ \\
\hline Mixed forests & $99,058.62$ & $102,642.04$ & $102,955.75$ & $104,499.25$ & $105,319.66$ \\
\hline Total forest area & $287,357.82$ & $303,544.12$ & $305,386.48$ & $303,786.47$ & $304,780.96$ \\
\hline \multicolumn{6}{|l|}{ South Moravia } \\
\hline Coniferous forests & $59,275.09$ & $59,144.17$ & $59,821.71$ & $59,670.05$ & $58,274.98$ \\
\hline Broad-leaved forests & $73,290.53$ & $76,020.69$ & $75,855.11$ & $75,433.30$ & $74,270.16$ \\
\hline Mixed forests & $63,624.92$ & $64,995.51$ & $65,372.68$ & $65,996.31$ & $65,103.12$ \\
\hline Total forest area & $196,190.54$ & $200,160.37$ & $201,049.50$ & $201,099.66$ & $197,648.26$ \\
\hline \multicolumn{6}{|l|}{ Czech Republic } \\
\hline Coniferous forests & $\begin{array}{c}1,655,719.55 \\
b *, c *, d *, e\end{array}$ & $1,701,653.96^{a *}$ & $1,722,612.13^{a *}$ & $1,692,347.40^{a *}$ & $1,665,902.94^{\mathrm{a}}$ \\
\hline Broad-leaved forests & $249,729.32$ & $277,702.87$ & $278,328.37$ & $283,601.69$ & $283,338.26$ \\
\hline Mixed forests & $585,415.17$ & $613,367.76$ & $617,417.94$ & $635,595.63$ & $643,699.92$ \\
\hline Total forest area & $\begin{array}{c}2,490,864.05 \\
\text { b,c,d,e }\end{array}$ & $2,592,724.59^{a}$ & $2,618,358.44^{a}$ & $2,611,544.72^{a}$ & $2,592,941 \cdot 12^{a}$ \\
\hline \multicolumn{6}{|c|}{ Inland water } \\
\hline \multicolumn{6}{|l|}{ Central Bohemia } \\
\hline Water courses & $1718.98^{b, d, e}$ & $1760.46^{\mathrm{a}}$ & 1753.10 & $1754.38^{\mathrm{a}}$ & $1754.38^{\mathrm{a}}$ \\
\hline Water bodies & 5114.35 & 5357.60 & 5444.30 & 5536.74 & 5582.84 \\
\hline Total water bodies & 6833.33 & 7118.06 & 7197.40 & 7291.12 & 7337.22 \\
\hline \multicolumn{6}{|l|}{ South Moravia } \\
\hline Watercourses & 245.01 & 64.68 & 136.32 & 221.52 & 221.51 \\
\hline Water bodies & 6637.31 & 6565.82 & 6577.38 & 6564.66 & 6564.66 \\
\hline Total water bodies & 6882.32 & 6630.50 & 6713.70 & 6786.18 & 6786.17 \\
\hline \multicolumn{6}{|l|}{ Czech Republic } \\
\hline Water courses & 4542.62 & 4496.86 & 4565.02 & 4685.48 & 4685.46 \\
\hline Water bodies & $49,292.53$ & $51,657.66$ & $52,037.13$ & $53,264.60$ & $53,608.38$ \\
\hline Total water bodies & $53,835.15^{\mathrm{e}}$ & $56,154.52$ & $56,602.15$ & $57,950.08$ & $58,293.84^{a}$ \\
\hline
\end{tabular}

${ }^{a}$ significant difference with the year $1990{ }^{b}$ significant difference with the year 2000; ${ }^{\mathrm{c}}$ significant difference with the year 2006; ${ }^{\mathrm{d}}$ significant difference with the year 2012; ${ }^{\text {e }}$ significant difference with the year 2018; ${ }^{*}: p<0.001$, without ${ }^{*}: p<0.05$.

Regarding the evolution of the Czech water body area by the type of inland water, there were no significant changes in the area concerning watercourses and bodies in the different periods. However, the total water bodies showed a significant increase between 1990 and 2018. Similarly, as reported in the national land use balance, surface water increased its area in the period 2000 to 2019. Between 2000, 2006, and 2012, there was no significant increase (Table 2).

Forest cover and watershed losses and gains in the country were also evaluated, as depicted in Table 3. The results presented a slight decrease in the total Czech forest area 
( $-0.98 \%$ ) from 2006 to 2018 , especially in the coniferous forest-around $-3.40 \%$. In contrast, the broad-leaved and mixed forests consistently increased over the years. Furthermore, the water body in 1990-2018 showed a steady incremental gain.

Table 3. Forest cover and water body changes from 1990 to 2006 and 2006 to 2018 and 1990 to 2018 in the Czech Republic.

\begin{tabular}{ccccccc}
\hline Type of Land Cover & \multicolumn{3}{c}{ Change Rate (ha/Year) } & \multicolumn{3}{c}{ \% of Area Changes $^{\mathbf{1}}$} \\
\hline & $\mathbf{1 9 9 0 - 2 0 0 6}$ & $\mathbf{2 0 0 6 - 2 0 1 8}$ & $\mathbf{1 9 9 0 - 2 0 1 8}$ & $\mathbf{1 9 9 0 - 2 0 0 6}$ & $\mathbf{2 0 0 6 - 2 0 1 8}$ & $\mathbf{1 9 9 0 - 2 0 1 8}$ \\
\hline Coniferous forests & 4180.79 & -4725.77 & 363.69 & +3.88 & -3.40 & +0.61 \\
\hline Broad-leaved forests & 1787.44 & 417.49 & 1200.32 & +10.28 & +1.77 & +11.86 \\
\hline Mixed forests & 2000.17 & 2190.17 & 2081.60 & +5.18 & +4.08 & -0.98 \\
\hline Total forest area & 7968.40 & -2118.11 & 3645.61 & +4.87 & +0.0004 & +3.94 \\
\hline Watercourses & 8.93 & -0.0017 & 5.10 & +3.05 & +3.05 \\
\hline Water bodies & 248.25 & 28.65 & 154.14 & +7.45 & +0.64 & +8.05 \\
\hline Total water bodies & 257.18 & 28.65 & 159.24 & +7.1 & +0.59 \\
\hline
\end{tabular}

${ }^{1}$ Percentage of area changes are defined using the given Formula (1) above.

Forest Cover and Water Bodies in the Case Study Areas

In 1990, the forests in the South Moravian region occupied about $18.8 \%$ of the total Czech forest area, which decreased to $16.7 \%$ in 2018, while the proportion of forested landscape in the Central Bohemian region increased slightly, from $11.1 \%$ in 1990 to $12.0 \%$ in 2018 (Table 2). The results of the CLC evolution in the selected years showed that the forest cover in the case study areas agreed with the national data. Forested landscapes in Central Bohemia and South Moravia had the highest increment in 2006, compared to $1990(+5.90 \%,+2.42 \%$, respectively). Meanwhile, a decrease in the total forest area was also found in these regions from 2006 to 2018 , by $-0.20 \%$ and $-1.72 \%$, respectively. The Central Bohemian region consistently showed the highest increase in total forest area, and the lowest loss of forest areas as well.

The water bodies in Central Bohemia increased by about $6.8 \%$ in 1990-2018, while they decreased by about $1.4 \%$ in South Moravia in the same period. On the other hand, the watercourses in Central Bohemia reported significant differences based on the Wilcoxon signed-rank test when comparing 1990 with 2000, 2012, and 2018, with a slight increase of around 2.0\% between 1990 and 2018. Conversely, South Moravia reported a reduction of $10.6 \%$ in the same period (Table 2 ).

\subsection{Water Quality}

Figure 4a shows the BOD load. A decrease is observed in 2010 and an increase from 2012 in the two regions. According to the load values in 2019, Central Bohemia reported a higher load of BOD (26,535 tons/2019), while South Moravia reported 26,180 tons / 2019. Figure $4 \mathrm{~b}$ shows the COD load, as the two regions indicate an increasing trend, while, since 2017, Central Bohemia has been more stable with its COD values $(54,807$ tons/2019) than South Moravia, which continues to increase in COD (61,014 tons/2019). Undissolved substances are presented in Figure 4c. Variable behavior is shown between 2009 and 2019. Central Bohemia showed a gradual increase from 2012, while South Moravia increased between 2012 and 2016, and then increased again until 28,745 tons were reported in 2019. The nitrogen totals (Figure $4 \mathrm{~d}$ ) indicate that the two regions tend to increase in value, and similarly to the COD, Central Bohemia tends to stabilize, while South Moravia continued its increase and reached 5547 tons in 2019. The phosphorus totals (Figure 4e) showed a similar trend to BOD. In 2011, the two regions decreased, and, as of 2012, have gradually increased their value, reaching totals of 745 and 706 tons in 2019 in Central Bohemia and South Moravia, respectively. 

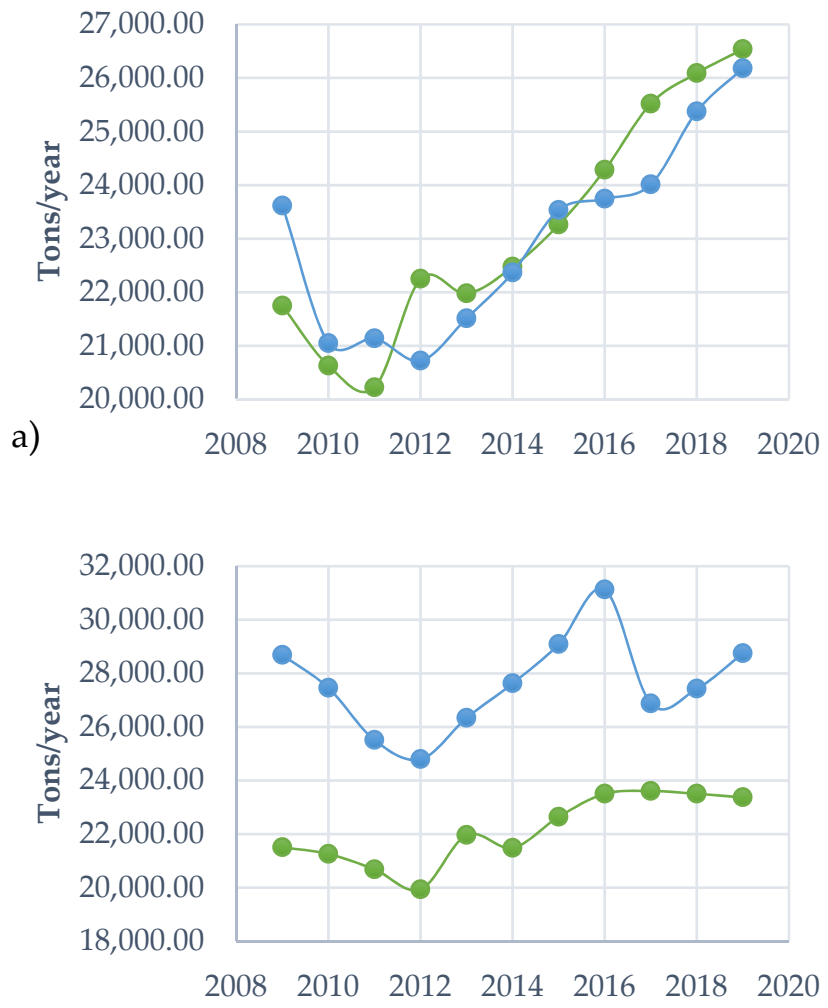

c)

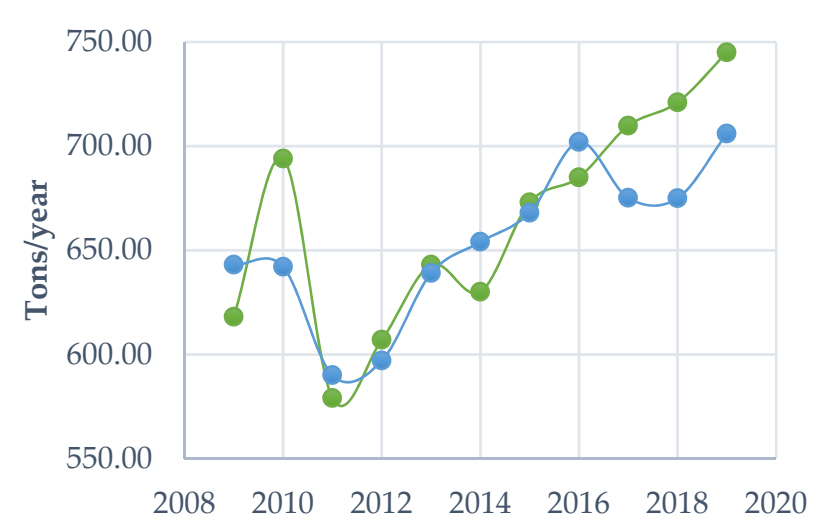

e) —-Central Bohemia $\longrightarrow$-South Moravia
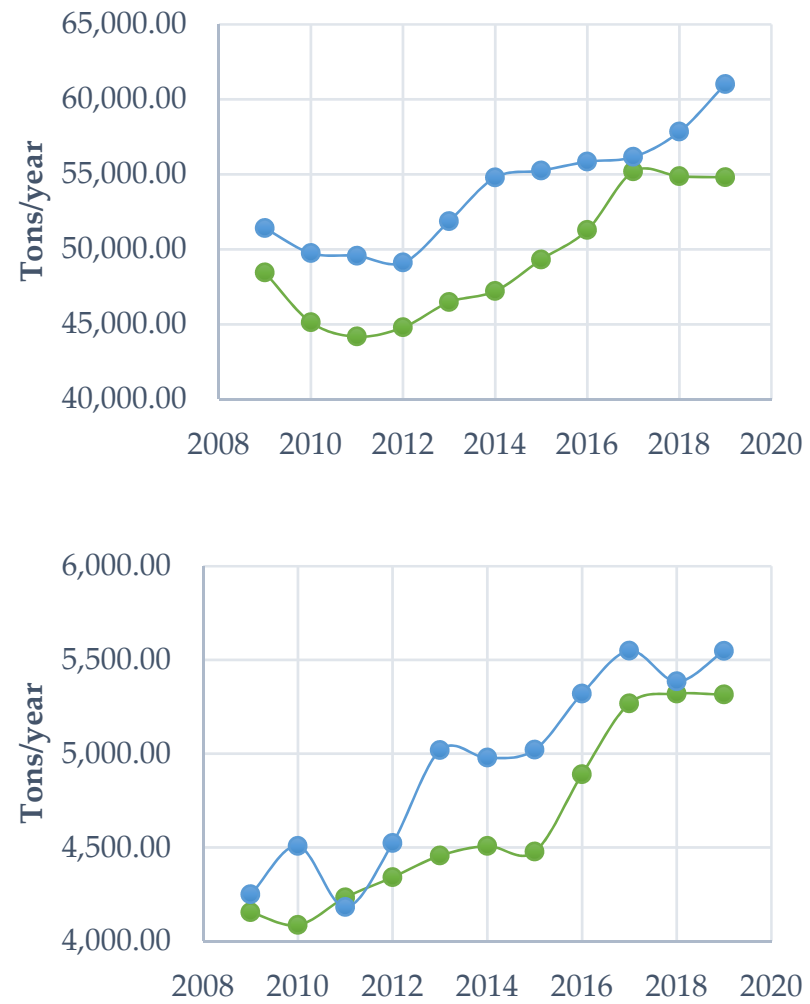

d) 


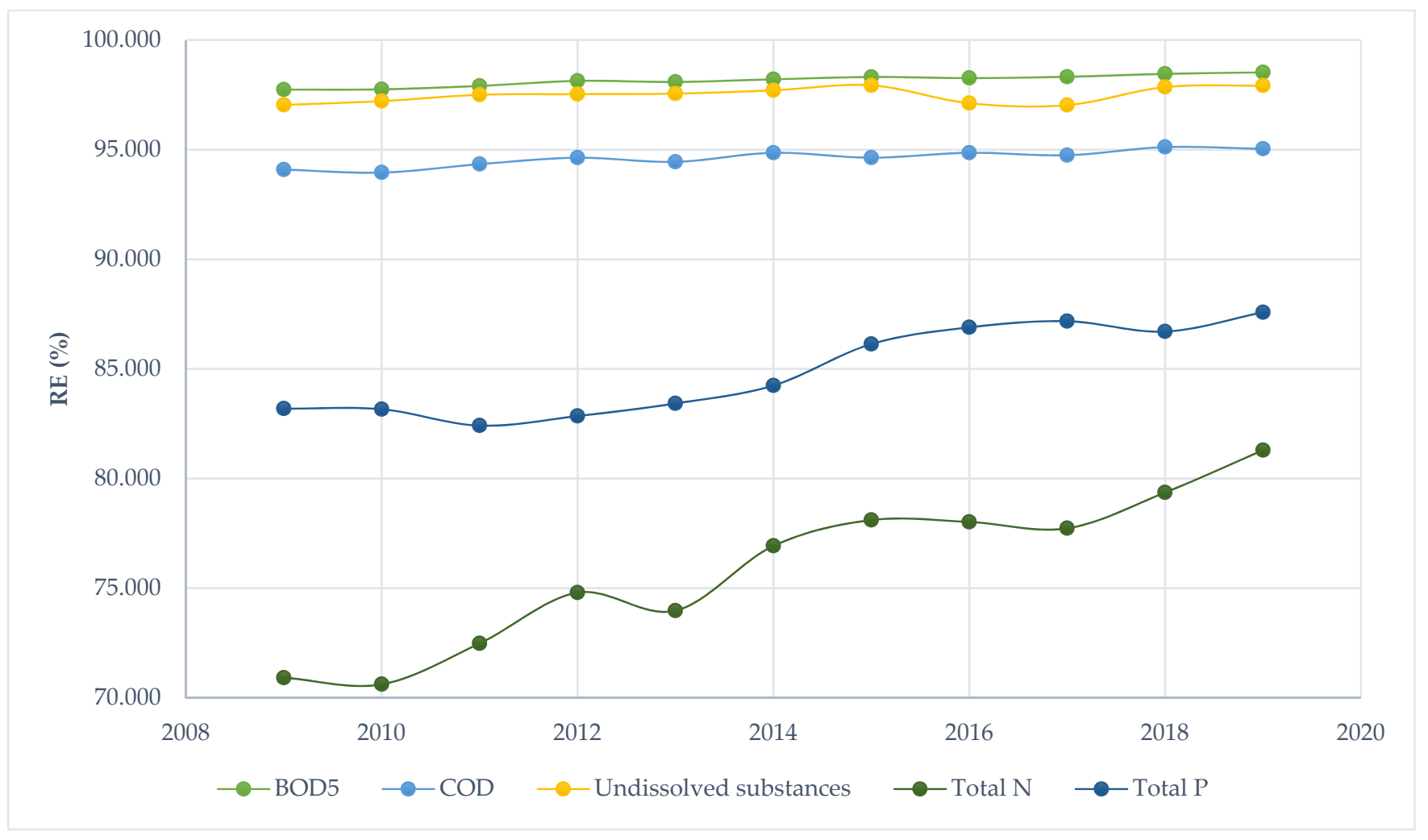

Figure 5. Removal efficiency or load reduction (\%) by WWTPs for each parameter in Czechia 2009-2019.

\subsection{Policy Instruments on Wastewater Management}

Figure 6 shows a continuous increase in non-investment spending between 2009 and 2019 in the Czech Republic. The investment in environmental protection indicated a significant increase in 2015, while in 2013 and 2016, there was a considerable decrease in the budget. As for the study areas, the environmental investment shows that, in 2015, the South Moravian region doubled its budget, while in the remaining years it increased and then decreased. Central Bohemia shows more stable behavior in 2009-2015; following this, it decreased in 2016 and then increased until 2019. Regarding the non-investment expenditure, the regions presented a marked increasing trend, similar to that reported nationwide, see Figure 7.

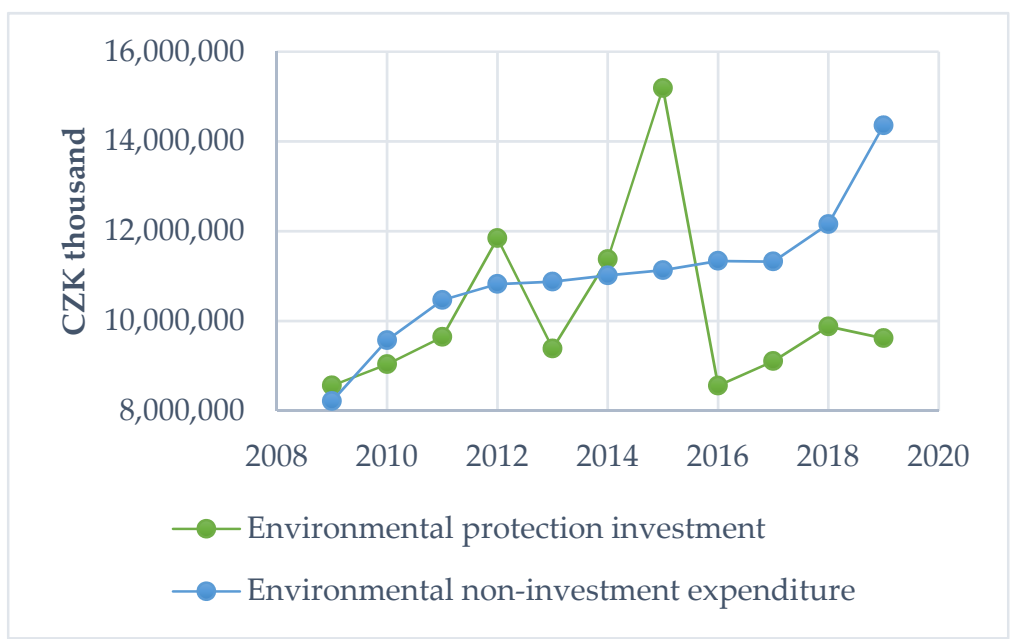

Figure 6. Environmental protection investment and non-investment expenditure on wastewater management in the Czech Republic during 2009-2019. 


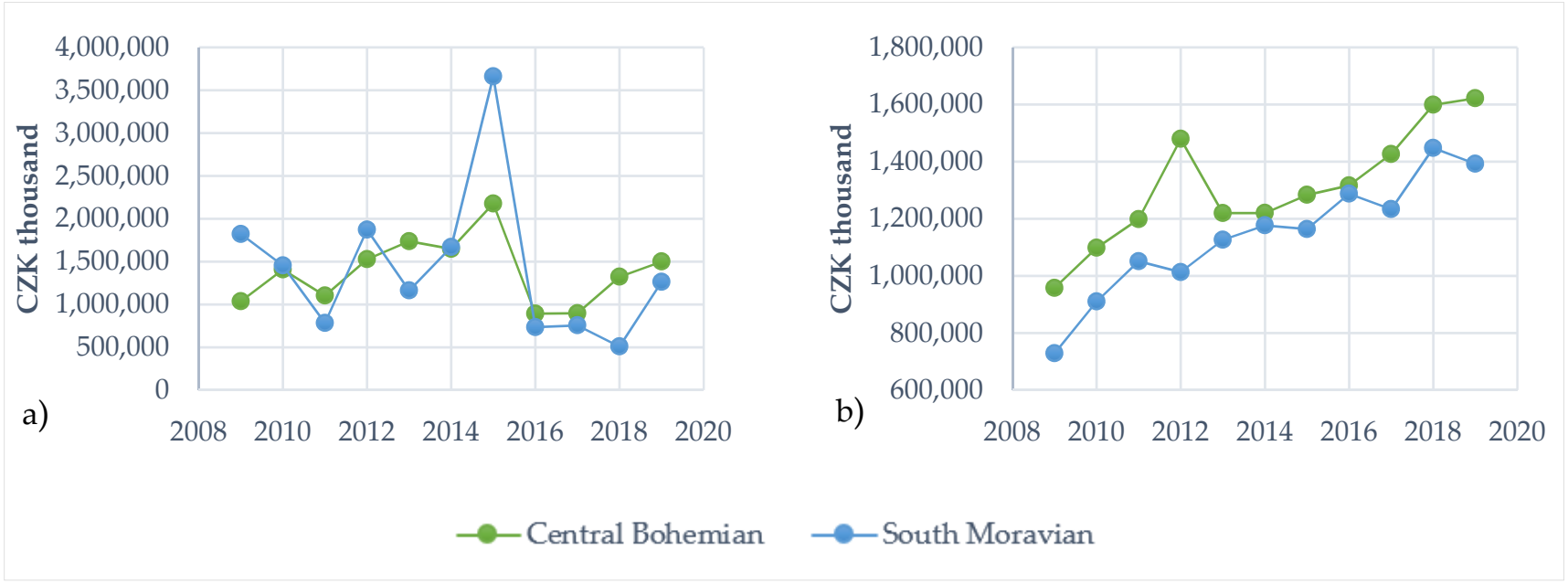

Figure 7. (a) Environmental protection investment and (b) non-investment expenditure (in CZK thousand) on wastewater management in selected regions.

In the selected regions, Spearman's non-parametric correlation showed a positive correlation between removal efficiency and the environmental non-investment expenditure on wastewater $\left(\mathrm{r}^{2}=0.358, \mathrm{n}=33, p<0.058\right)$. Central Bohemia and South Moravia indicated a positive correlation between removal efficiency and the environmental non-investment expenditure on wastewater $\left(\mathrm{r}^{2}=0.873, \mathrm{n}=11, p<0.01\right.$ and $\mathrm{r}^{2}=0.882, \mathrm{n}=11, p<0.01$, respectively). No significant correlation was reported in the selected regions between the environmental protection investment and removal efficiency of wastewater treatments in WWTPs in the Czech Republic.

The number of WWTPs in Czechia increased from 2158 in 2009 to 2759 in 2020. In the same period, the Central Bohemian and South Moravian regions also increased from 415 to 542 , and from 198 to 267 , respectively. Regarding the total capacity in $\mathrm{m}^{3}$ /day, Czechia reported 4,249,704 in 2020 and 3,832,673 in 2009. Central Bohemia reported 351,719 and South Moravia reported 339,572 in 2020 [84].

\subsection{Public Perception}

Of the total recruited respondents, 1338 were included in the analysis because they were able to judge the expectations of the water provisioning services of the Czech forests and their performance level. Furthermore, 170 and 147 respondents from the Central Bohemian and South Moravian regions, respectively, were also selected for the analysis. Table 4 presents the general characteristics of the respondents in each region, and compares the results to the total of the Czech respondents selected. The Central Bohemian respondents were significantly older than the others, most of them possessing the national secondary school leaving certificate (maturita). Most of the respondents also lived in a town with less than 20,000 inhabitants, although the area was the second most populated region after the capital city of Prague [106]. Meanwhile, the highest proportion of respondents with higher education levels (66.9\%), living in the town with more than 20,000 inhabitants, were found in the South Moravian region (38.3\%). 
Table 4. General characteristics of the respondents ${ }^{1}$.

\begin{tabular}{|c|c|c|c|}
\hline \multirow[b]{2}{*}{ Characteristics } & \multicolumn{3}{|c|}{ Regions } \\
\hline & $\begin{array}{l}\text { Central Bohemian } \\
\qquad(\mathrm{n}=\mathbf{1 7 0})\end{array}$ & $\begin{array}{l}\text { South Moravian } \\
(\mathrm{n}=147)\end{array}$ & $\begin{array}{l}\text { Czech Republic } \\
\quad(N=1338)\end{array}$ \\
\hline Gender (male) & $50.6(86)$ & $46.3(68)$ & $51.2(685)$ \\
\hline Age (years) ** & $44.9 \pm 12.9$ & $39.0 \pm 13.8$ & $42.3 \pm 13.4$ \\
\hline \multicolumn{4}{|l|}{ Education level $*$} \\
\hline $\begin{array}{l}\text { Without the secondary school leaving } \\
\text { certificate (maturita) }\end{array}$ & $39.4(67)$ & $34.0(50)$ & $39.5(528)$ \\
\hline $\begin{array}{l}\text { With the secondary school leaving } \\
\text { certificate (maturita) and higher } \\
\text { Size of the town }\end{array}$ & $60.6(103)$ & $66.0(97)$ & $60.5(810)$ \\
\hline Less than 20,000 inhabitants & $82.4(140)$ & $62.6(92)$ & $57.7(772)$ \\
\hline$\geq 20,000$ inhabitants & $17.6(30)$ & $37.4(55)$ & $42.3(566)$ \\
\hline \multicolumn{4}{|l|}{ Frequency of forest visits } \\
\hline More than two times per year & $77.1(131)$ & $77.6(114)$ & $78.0(1044)$ \\
\hline Two times/year or less and never & $22.9(39)$ & $22.4(33)$ & $22.0(294)$ \\
\hline
\end{tabular}

${ }^{1}$ Data are presented using mean $\pm \mathrm{sd}$, or $\%(\mathrm{n})$; for comparing means between regions, non-categorical data were analyzed using ANOVA, while a chi-square test was used to analyze the categorical data; ${ }^{*} p$-value $<0.05 ;{ }^{* *} p$-value $<0.001$.

Generally, no statistically significant differences were found between the selected regions compared with the entire respondents. The total Czech respondent's expectation was confirmed by the perceived performance level based on the results of Spearman correlation $(r=0.442)$, a similar trend was found among the respondents in the South Moravian; in contrast, the Central Bohemian respondents had less expectation on the forests in providing the water source. The mean of forests' expectation was above three and the mean perceived performance level in providing water sources was 4.3 in the three study areas (Figure 8 ).

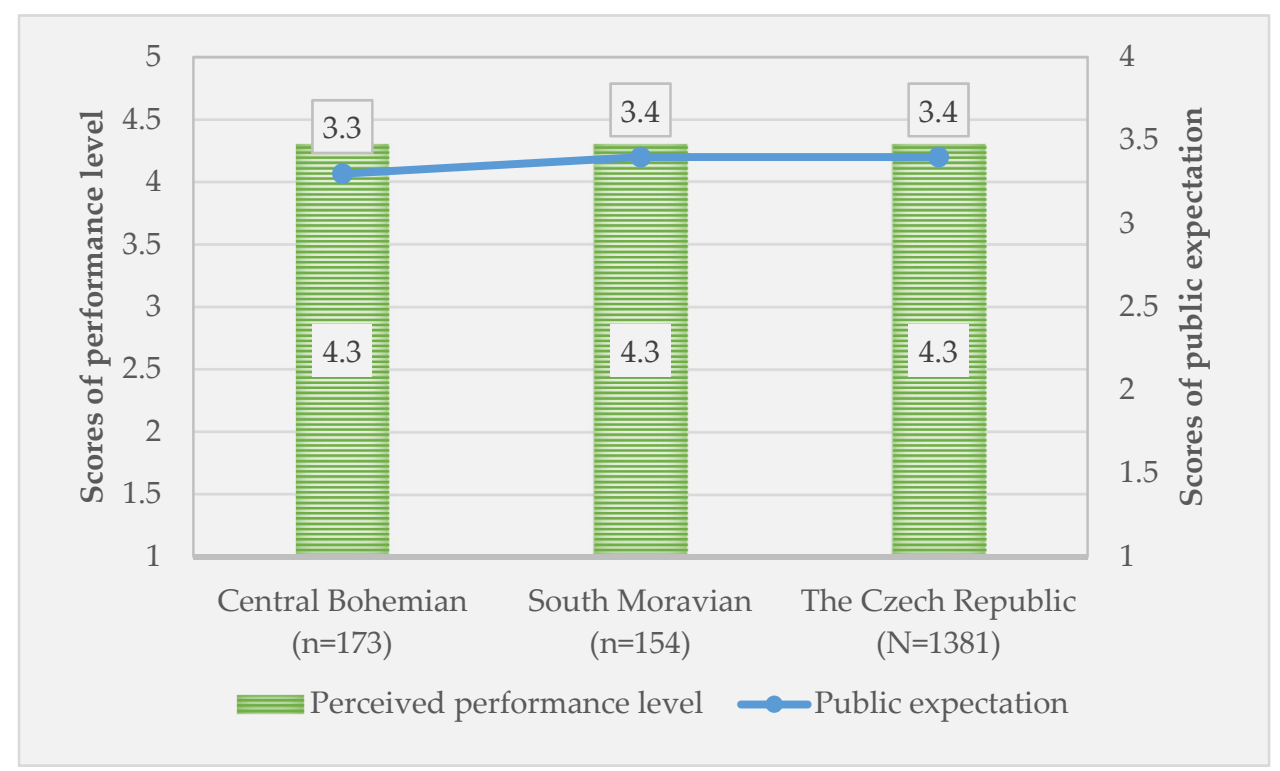

Figure 8. Mean of expectation and perceived performance level of the Czech forests on water provisioning services.

\section{Discussion}

In order to answer the research questions, the studied factors were grouped to present the interactions and the effects identified throughout the periods analyzed, with respect to the hydrologic ecosystem service. 


\subsection{Forest and Water Area Evolution in the Czech Republic}

Since 1995, when the Forest Act came into force, Czechia has declared the intention to protect forest areas that provide non-wood functions to the forest, such as the protection of water, soil, and the preservation of biological diversity, among others. Those areas are called special purpose forests and are recognized by the state forest administration, or by the initiative of the forest owner [107]. Similarly, the legal framework of the forest sector in the Czech Republic, following European policies, has allowed the sustainable development of the forest, through various documents to identify forest problems and propose solution measures, as well as monitoring, harvesting, disease control, research, grants, and incentives. The evolution of the National Forest Programs has allowed ministerial cooperation and the establishment of governmental entities, such as the Forests of the Czech Republic State Enterprise, Forest Management Institute, and Forestry and Game Management Research Institute [108,109]. Moreover, the analysis of the relationship between water and forests is aligned with the EU forest strategy, by recognizing the role of forests and their multifunctionality in the provision of socio-economic services [110].

A significant increase in the Czech forest area, since the 1990s to the selected years, have been observed. The highest incremental percentage (+4.87\%) was found in 1990-2006 (differences: 127,494.39 ha). After 2006, the forest areas slightly decreased, which was the most pronounced in $2018(-0.98 \%)$, cf. Table 2. Until 2017, the net annual increment was consistently higher than the total felling. However, from 2018 onwards, the total felling exceeded the net annual increment, due to a high demand for timber in a small region $[98,100]$, exacerbated by massive salvage logging that was caused by bark beetle infestation of the coniferous trees [83,111]. These problems have caused the country to experience economic, social, and environmental losses. During the last few years, bark beetles have been reported to have exponentially increased in Europe, due to climate change [112-114]. Furthermore, the state owns more than half $(54.09 \%)$ of the Czech forests, and most of the forests are managed by the state forest enterprises. The remaining forest land is owned by private entities $(19.27 \%)$, municipalities $(17.17 \%)$, communes and associations $(5.00 \%)$, as well as legal entities (3.27\%) [98]. The state forests applied a more bureaucratic system to forest management, and were the role model for the private forests. Since the bark beetle infestation has caused more economic damage for the private than the state forests, the private owners need to take action earlier, e.g., by diversifying their products. The country also provided subsidies, compensation, and recovery payments of EUR 259 million in 2018-2019 [115]. According to the national accounts in 2019, private owners received CZK 8,046,000 for landscape and biodiversity protection, including, for example, the restoration and preservation of habitat and species, natural and semi-natural types of landscape, and environmental stability elements [56].

The larger area of forest (range: 0.72 to 1.90) reported in the CLC in the selected years, compared to the national report by the Czech MoA, and the smaller area of water bodies reported in the CLC $(58,294 \mathrm{ha})$, compared with the land balance report $(167,000 \mathrm{ha})$, can be attributed to the following two reasons: (1) the minimum mapping unit of 25 ha in the CLC, and (2) the differences in classification categories. The significant disparities in the total areas might have also been caused by the fact that the mixed-forest areas in the CLC were reported as either coniferous or broad-leaved forests in the national report. The land use balance only includes surface water bodies, while the CLC includes watercourses as well. Complementary data, with a higher level of detail, are required in different periods to be able to compare the changes in the water bodies with greater certainty.

The slightly decreased forest areas after 2012, and even more in 2018, compared to the year 2006, can be attributed to the bark beetle calamity experienced by the country, especially after 2017, which resulted in a massive clear-cutting of coniferous trees [116].

In regards to the increasing water body area in both the CLC and the official land balance report, this phenomenon is surprising compared to the global trend of the reduction in freshwater area due to natural phenomena [117], and the pressure exerted on freshwater worldwide, since almost $70 \%$ is affected by the industrial sector, through its use and 
pollution [118]. Additionally, it is widely known that Czechia is highly dependent on rainfall and runoff conditions [66]. Between 2014 and 2018, the reported surface water levels were affected by the accumulated drought of previous years; in 2018, the total precipitation was the lowest since 1961 [111]. Thus, it is presumed that the water bodies included in the CLC and the national report include artificial structures that have been used to improve the management of waterways since 1991, as water channels for irrigation or drainage fields $[65,111]$, which distorts the mapping of the area occupied by water bodies.

\subsection{Forest-Water Interaction and Public Perception}

Forest-water interactions have been reported to provide essential and complex pathways for optimizing land use practices and water availability. The water system is susceptible to climate change; as the Earth's surface warmed, freshwater experienced, for example, a high rate of evaporation, a change in precipitation quantity and quality, and modifications of soil strength and biodiversity, which altered the quality and quantity of the groundwater. The frequency of flooding has also changed [119-121]. Forests are closely related to water, and also to the changes in land cover locations, such as riparian areas, alluvial plains, and wetlands. Any modifications in the quality of the structure and functioning of the landscape reduces the diversity and ecological processes taking place in an ecosystem $[35,60,61,121]$. Forests contribute to the regulation of the water cycle. Excessive rainwater is channeled along branches and trunks, reducing erosion of the soil, and the concentration of leaves in the soil facilitates the infiltration of water into the water table [35,122]. Water quality improves in the forest because there is less discharge of pollutants compared to industrial, settlement, and agricultural areas. The forest root network acts as a filter, reducing the levels of pollutants [121,123]. Additionally, the composition and state of the forest can vary the effects on water, e.g., heterogeneous forests have higher interception and redistribution of rainfall [122]. In cases such as this, sustainable forest management is expected to restore and improve groundwater recharge, global surface cooling, and water flow.

The low score of the FES performance evaluation was significantly associated with low education levels, and negatively associated with the age of the respondents $(p=0.001)$. A higher education level was found to have a link with positive behavior towards forest conservation [124]. The results of the survey implied the importance of forest education, especially on the role of the forest ecosystem with water provisioning services, to various audiences with different education levels, for supporting the forest policy to protect these areas, so they can function properly. The results indicate the importance of promoting the role of the Czech FES in water provisioning services among the older population and lower education levels, by improving the knowledge and awareness of the role of the Czech FES. The social protection of the forests will also increase, e.g., willingness to protect the trees from extended logging activities, and providing support to mixed forests to increase the health and vitality of the forests from insect attack $[35,39]$.

\subsection{Water Quality-Instruments Interaction and Public Perception}

Biological oxygen demand (BOD) and chemical oxygen demand (COD) have been globally acknowledged as indicators for organic load in wastewater $[125,126]$. Nitrogen totals ( $\mathrm{N}$ total) and phosphorus totals ( $\mathrm{P}$ total) may suggest nutrient stability and indicate eutrophication [127-129]. N total and $\mathrm{P}$ total are typical representative parameters of domestic wastewater [130] related to the human excreta [67], as well as household chemicals, such as detergents [131], and substances related to agricultural practices [132], while undissolved substances may be closely related to the existence of suspensions in water [133].

High organic loads in South Moravia (BOD 26,180 tons/year in 2019) may be caused by the high production of wastewater related to both demographic and industrial issues. Figure 3 a reveals that the drop in BOD load occurred in 2010 for WWTPs in South Moravia, but there was only a slight decrease in COD load in the same year. This is expected to be due to the presence of potential substances that are not simply degraded by biological 
activities, since BOD indicates the level of biodegradable fraction in wastewater [134]. Further regional observation and confirmation regarding this assumption are required to identify certain relevant practices that this load might have potentially originated from. Among the studied regions, South Moravia represented the highest population density in 2019 [76] $\left(165.2 \mathrm{~km}^{2}\right)$, indicating a higher production of domestic wastewater. Meanwhile, industrial activities may generate a high load of COD (61.014 tons/year in 2019) containing compounds that are not readily biodegradable and inhibit the activity of aerobic bacteria. In view of the fact that industry constitutes the most essential sector in South Moravia, there is a tendency to enhance the higher value of production, due to shifts in structures and businesses, resulting in a higher intensity of industrial activities. Moreover, foreign investors predominantly allocate their investments in Brno and Modrice-the locations with the most extensive industrial terminals in South Moravia [135].

Generally, South Moravia tends to take a lead in terms of the load values of undissolved substances during the studied period, which predictably occurred due to the fact that more inhabitants lived in residential areas connected to the sewerage system from 2009 (87.9\%) to 2019 (90.3\%) than in Central Bohemia (66.5\% in 2009 and 74.4\% in 2019) [91,136]. If a larger number of inhabitants linked to the sewerage system is associated with a presumption of more wastewater discharged to the WWTPs inflow, it leads to an assumption that the WWTPs examined in South Moravia received a heavier load of undissolved substances compared to Central Bohemia. However, for further observation, we would require the information related to the sampling season frequency in WWTP per year, as the presence of undissolved substances is also influenced by dry or rainy weather [137,138]. Concerning nitrogen, South Moravia showed higher values, similar to the other parameters, possibly due to a greater number of inhabitants living in sewage system-equipped municipalities $(1,073,942)[139]$, leading to the higher production of discharged nutrient loads.

Meanwhile, total phosphorus is frequently appraised as an indicator of the nutrients transported by runoff (dissolution or erosion), mainly from agricultural activities [132,140]. To the best of our knowledge, the assumption regarding the pattern of $\mathrm{P}$ total load in Figure $4 \mathrm{f}$ is associated with the mode of agricultural management and practices, since it can influence the fluctuation of the phosphorus state in the soil [140]. In addition, the increase in total P load in WWTPs inflow, starting from 2011 to 2019, is also predicted to be due to the increase in agricultural area in both the regions between 2006 and 2018 (based on our data analysis from CLC database), indicating that more agricultural practices were intensified. A specific evaluation of agricultural management, practices, policy, and sampling method from both the regions should be taken into account to support our prediction regarding the pattern of P total load.

The analysis of water quality parameters allows the visualization that the water treated in the plants can reduce its pollutant load; however, the quality of the other water bodies that cover the Czech Republic is unknown, and that can affect the provision of freshwater. According to the annual water reports, regions with polluted to highly polluted water quality are identified $[77,78,141]$, especially near urban settlements and industrial zones, which can compromise the provision of freshwater and other services [25,30,35].

The removal efficiency average of all the parameters that are comparatively examined for Central Bohemia, South Moravia, and the nationwide Czech Republic encountered high average values, proven by the ability to fit removal threshold requirements for all the measured parameters, adjusted by UWWTD. Despite the concern of South Moravia possessing a low level of water quality, as observed by several reports [48,78], the data analysis in our study pointed out that this region occupied the highest value of RE average over a period of time, compared to Central Bohemia, concerning its performance in achieving a higher $\mathrm{RE}$ for all the measured parameters. A study by Janosova [48] reported that a WWTP in Kyjov, South Moravia, employed physical and biological processes for the pretreatment of collected sewage and combinative systems, such as a circulating activation tank, secondary settling tanks, and a pumping installation used for recirculated and excess sludge. This set of techniques can be associated with the removal efficiency analysis in South Moravia. 
However, further examination is necessary to identify the detailed specification of the treatment appliances of the WWTPs applied on a regional scale, corresponding to the raw data, as well as their retention time processing and the state of the sampling season regime.

According to previous results, the significant improvement of water treatment systems and the increase in the number of WWTPs can be attributed to a series of environmental policies and economic instruments implemented to conserve natural resources and protect the landscape $[70,142,143]$. Specifically, compliance with the UWWTD, to modernize and build new wastewater treatment plants before 2010, was a requirement that was established upon the entry into the EU. Since 1997, large financial investments have been required, mainly supported by the Instrument for Pre-Accession Structural Assistance, and structural and cohesion funds, before and after entering the European Union, respectively $[143,144]$, to comply with the EU Directives on water.

Despite not finding a significant correlation between the environmental protection investment and removal efficiency of wastewater treatment in WWTPs, it is evident that the investment used in the infrastructure increases the capacity of WWTPs in the country, as well as the level of compliance with UWWTD, as confirmed by the OECD in its report [71]. However, it was identified that the environmental investment reports lack specific information on the costs and expenses of the specific activities that are developed for wastewater management. More studies are required that use detailed information on investments to verify, with greater certainty, the effectiveness of these investments.

The challenges due to climate change require investments to continue to implement more and better measures of mitigation and adaptation, as structures for water storage, innovation for the use of ground and surface water, capture and reuse of wastewater, protection of sources from which the water supply originates, and alignment with the Sustainable Development Goals on clean water, sanitation, and water life [117].

Environmental investment in processes that improve, treat, or remedy the physicochemical state of water is considered essential if properly developed [145]. Additionally, it is vital to develop land use and water policies that integrate people's perceptions, maintaining a balance between ecosystem services, users, and economic development [61]. In addition, the general public and two case study areas (the Central Bohemian and South Moravian regions) perceived that the Czech forests could still provide and deliver a good clean water source (range of mean was 3.3-3.4 from the total four scores). The predictor analysis, using binary logistic regression, revealed that the respondents' age had a negative and significant correlation with the low score of perception on the Czech forest ecosystem's ability to provide a clean water source. Community perception could provide current insights and firsthand experiences of the people [51,52], as our preliminary results of public perception showed that the younger generation seemed to have an unfavorable view of the forest ecosystem's ability to provide clean water. Future research is needed to investigate the reasons for their opinions.

\section{Conclusions}

The change in forest cover, based on the CLC database, in 1990, 2000, 2006, 2012, and 2018 presented the evolution of forests in the Czech Republic, and pointed to the importance of addressing the decline in forest areas in 2018, which was confirmed by the current national forest report. Two of the main causes were the bark beetle incursion and weather events, such as the Kyrill windstorm of 2007. The decline in forested landscapes has been reported in the case study regions as well.

The water body area showed an increase between 1990 and 2018. It is presumed that the CLC database and the land use balance report included artificial structures that distorted the mapped area. However, the comparison of water reports allowed us to identify that between 2014 and 2018, the levels of surface water were affected by the accumulated drought from the previous years. The relatively stable forest areas in the Central Bohemian and South Moravian regions were positively linked to the water bodies. 
The expectations and perceived performance of the community were used to understand the relationship between the FES and the provision of freshwater. It was identified that respondents with a low educational level and an older population score provided a low-performance valuation of the FES, which calls attention to the importance of integrating the forest ecosystem with the water supply services to encourage various audiences, with different education levels, to support forest policies to protect forest areas, so that they can function properly.

The Czech Republic and the study regions met the removal efficiency or load reduction threshold among the measured parameters suggested by the UWWTD (BOD, COD, undissolved substance, $\mathrm{N}$ total, and $\mathrm{P}$ total), by more than 75\%, 70-90\%, 50\%, 75\%, and $75 \%$, respectively, in wastewater treatment plants. Also, the number of WWTPs increased from 2158 in 2009 to 2759 in 2020.

The significant improvement in effluence quality and the increased number of WWTPS can be attributed to environmental protection expenditures that were created to implement environmental policies in wastewater management. Therefore, it is suggested to continue investing in controlling water pollution, building new wastewater treatment plants, and improving the existing ones to reduce the harmful risks for hydrological ecosystem services.

The environmental policies can significantly influence the services of hydrological ecosystems, according to land use, investment programs and the development of sustainable activities, directives to control pollution, and initiatives that promote knowledge transfer to generate awareness and commitment of society. In this sense, it is expected that the framework of European and Czech environmental policies will be maintained, where short- and long-term strategies establish an increase in forest cover, public participation, and investment in technological improvement, to reduce pollution in water and other resources.

It was identified that the hydrological ecosystems of the Czech Republic and the study areas present natural and anthropic pressures, such as the bark beetle infestation, climatic events that affect the water regime, and the availability of the resource. Similarly, it was identified that water resources present a high load of pollutants before being treated in the WWTPs, which modifies the conditions and availability of the water bodies that do not enter the water treatment system. Finally, it was identified that some groups in society lack knowledge about the benefits and effects of the forest in providing services, which could eventually put pressure on the resource, by not valuing its ecosystem importance.

The study provides information on multi-pronged analyses that can be developed to investigate the interactions between the components of nature, society, and the economy, allowing decision makers to use their findings to promote management and investment measures according to the needs of hydro-ecosystem services. Similarly, the findings can be used to promote inter-ministerial cooperation, to develop activities, spend budgets more effectively, and improve the current state of resources that provide ecosystem services to society. Additionally, this kind of analysis opens up possibilities for future research that promotes understanding the complexity of ecosystems, and identifying the changing needs of forests and water resources for sustainable development.

Author Contributions: Conceptualization, D.C.H.B., R.C.P. and M.H. (Miroslav Hájek); methodology, D.C.H.B., R.C.P., M.C.P. and M.H. (Miroslav Hájek); software, D.C.H.B. and R.C.P.; formal analysis, D.C.H.B., R.C.P. and M.C.P.; investigation, D.C.H.B., R.C.P. and M.C.P.; data curation, D.C.H.B. and R.C.P.; writing-original draft preparation, D.C.H.B., R.C.P., M.C.P. and M.H. (Miroslav Hájek); writing—review, D.C.H.B., R.C.P., M.C.P., M.H. (Miroslav Hájek), M.T., P.P., M.H. (Miroslava Hochmalová); editing D.C.H.B.; supervision, M.H. (Miroslav Hájek). All authors have read and agreed to the published version of the manuscript.

Funding: This paper was supported by the grant "EVA4.0, No. CZ.02.1.01/0.0/0.0/16_019/0000803", financed by the Operational Program Research, Development and Education, the Ministry of Education, Youth and Sports of the Czech Republic. 
Data Availability Statement: CLC database is available on https: / land.copernicus.eu/pan-european/ corine-land-cover (accessed on 1 June 2021); water quality and environmental accounts are available on https: / / www.czso.cz/ (accessed on 15 June 2021).

Acknowledgments: The authors appreciate the support from the project, "Advanced research supporting the forestry and wood-processing sector's adaptation to global change and the 4th industrial revolution" and the project, "Diversification of the Impact of the Bioeconomy on Strategic Documents of the Forestry-Wood Sector as a Basis for State Administration and the Design of Strategic Goals" at the Faculty of Forestry and Wood Sciences, Czech University of Life Sciences, Prague.

Conflicts of Interest: The authors declare no conflict of interest.

\section{References}

1. Costanza, R.; d'Arge, R.; Groot, R.; Farber, S.; Grasso, M.; Hannon, G.; Limburg, K.; Naeem, S.; O'Neill, R.; Paruelo, J.; et al. The Value of the World's Ecosystem Services and Natural Capital. Nature 1997, 387, 253-260. [CrossRef]

2. European Commission; University of the West of England (UWE). Science for Environment Policy. In-Depth Report. Ecosystem Services and Biodiversity; Publications Office: Bristol, UK, 2015; ISBN 978-92-79-45725-8.

3. Ciscar, J.-C.; Soria, A.; Goodess, C.M.; Christensen, O.B.; Iglesias, A.; Garrote, L.; Moneo, M.; Quiroga, S.; Feyen, L.; Dankers, R. Climate Change Impacts in Europe. Final Report of the PESETA Research Project; European Commission: Luxembourg, $2009 ;$ p. 132. ISBN 978-92-79-14272-7.

4. Ford, C.R.; Laseter, S.H.; Swank, W.T.; Vose, J.M. Can Forest Management Be Used to Sustain Water-Based Ecosystem Services in the Face of Climate Change? Ecol. Appl. 2011, 21, 2049-2067. [CrossRef] [PubMed]

5. Reid, W.V.; Mooney, H.A.; Cropper, A.; Capistrano, D.; Carpenter, S.R.; Chopra, K.; Dasgupta, P.; Dietz, T.; Duraiappah, A.K.; Hassan, R.; et al. Ecosystems and human well-being-Synthesis: A report of the Millennium Ecosystem Assessment; Island Press: Washington, DC, USA, 2005; ISBN 9781597260404.

6. Haines-Young, R.; Potschin, M. Common International Classification of Ecosystem Services (CICES) V5.1. Guidance on the Application of the Revised Structure; Fabis Consulting Ltd.: Nottingham, UK, 2018; p. 53.

7. Marusakova, L.; Sallmannshofer, M.; Tyrvainen, L.; O’Brien, L.; Bauer, N.; Schmechel, D.; Kaspar, J.; Schwarz, M.; Krainer, F. Human Health and Sustainable Forest Management; Liaison Unit: Bratislava, Slovakia, 2019; pp. 17-20. ISBN 978-80-8093-265-7.

8. Gleick, P.H. Water in Crisis: A Guide to the World's Fresh Water Resources; Oxford University Press: Oxford, UK, 1993; Volume 9, p. 473. ISBN 9780195076288.

9. Yamashita, S. Perception and Evaluation of Water in Landscape: Use of Photo-Projective Method to Compare Child and Adult Residents' Perceptions of a Japanese River Environment. Landsc. Urban Plan. 2002, 62, 3-17. [CrossRef]

10. West, A. Core Concept: Ecosystem Services. Proc. Natl. Acad. Sci. USA 2015, 112, 7337-7338. [CrossRef]

11. De Groot, R.S.; Alkemade, R.; Braat, L.; Hein, L.; Willemen, L. Challenges in Integrating the Concept of Ecosystem Services and Values in Landscape Planning, Management and Decision Making. Ecol. Complex. 2010, 7, 260-272. [CrossRef]

12. Grizzetti, B.; Lanzanova, D.; Liquete, C.; Reynaud, A.; European Commission; Joint Research Centre \& Institute for Environment and Sustainability. Cook-Book for Water Ecosystem Service Assessment and Valuation; Publications Office: Luxembourg, 2015; ISBN 978-92-79-46199-6.

13. Moser, G. Water Quality Perception, a Dynamic Evaluation. J. Environ. Psychol. 1984, 4, 201-210. [CrossRef]

14. West, A. Optical Water Quality and Human Perceptions of Rivers; University of Arkansas: Fayetteville, AR, USA, 2016 ; p. 158.

15. Turgeon, S.; Rodriguez, M.J.; Thériault, M.; Levallois, P. Perception of Drinking Water in the Quebec City Region (Canada): The Influence of Water Quality and Consumer Location in the Distribution System. J. Environ. Manag. 2004, 70, 363-373. [CrossRef]

16. de França Doria, M.; Pidgeon, N.; Hunter, P.R. Perceptions of Drinking Water Quality and Risk and Its Effect on Behaviour: A Cross-National Study. Sci. Total Environ. 2009, 407, 5455-5464. [CrossRef]

17. Francis, M.R.; Nagarajan, G.; Sarkar, R.; Mohan, V.R.; Kang, G.; Balraj, V. Perception of Drinking Water Safety and Factors Influencing Acceptance and Sustainability of a Water Quality Intervention in Rural Southern India. BMC Public Health 2015, 15, 731. [CrossRef]

18. Di Gregorio, A.; Food and Agriculture Organization of the United Nations (FAO) (Eds.) Land Cover Classification System: Classification Concepts and User Manual; Software Version 2; Environment and Natural Resources Series GEO-spatial Data and Information; Food and Agriculture Organization of the United Nations: Rome, Italy, 2005; ISBN 978-92-5-105327-0.

19. Pongratz, J.; Dolman, H.; Don, A.; Erb, K.-H.; Fuchs, R.; Herold, M.; Jones, C.; Kuemmerle, T.; Luyssaert, S.; Meyfroidt, P.; et al. Models Meet Data: Challenges and Opportunities in Implementing Land Management in Earth System Models. Glob. Change Biol. 2018, 24, 1470-1487. [CrossRef]

20. Shukla, P.; Skea, J.; Calvo Buendia, E.; Masson-Delmotte, V.; Pörtner, H.; Roberts, D.; Zhai, P.; Slade, R.; Connors, S.; van Diemen, R.; et al. IPCC, 2019: Climate Change and Land: An IPCC Special Report on Climate Change, Desertification, Land Degradation, Sustainable Land Management, Food Security, and Greenhouse Gas Fluxes in Terrestrial Ecosystems; IPCC: Toronto, ON, Canada, 2019.

21. Kosztra, B.; Büttner, G.; Hazeu, G.; Arnold, S.; Environment Agency Austria. Updated CLC Illustrated Nomenclature Guidelines; Environment Agency Austria: Wien, Austria, 2019; p. 126. 
22. Bojinski, S.; Verstraete, M.; Peterson, T.C.; Richter, C.; Simmons, A.; Zemp, M. The Concept of Essential Climate Variables in Support of Climate Research, Applications, and Policy. Bull. Am. Meteorol. Soc. 2014, 95, 1431-1443. [CrossRef]

23. Bielecka, E.; Jenerowicz, A. Intellectual Structure of CORINE Land Cover Research Applications in Web of Science: A Europe-Wide Review. Remote Sens. 2019, 11, 2017. [CrossRef]

24. Boucníková, E.; Kucera, T. How Natural and Cultural Aspects Influence Land Cover Changes in Czech Republic. Ekológia Bratisl. 2005, 24 (Suppl. 1), 69-82.

25. Cabral, P.; Feger, C.; Levrel, H.; Chambolle, M.; Basque, D. Assessing the Impact of Land-Cover Changes on Ecosystem Services: A First Step toward Integrative Planning in Bordeaux, France. Ecosyst. Serv. 2016, 22, 318-327. [CrossRef]

26. Nobre, C.A.; Sellers, P.J.; Shukla, J. Amazonian Deforestation and Regional Climate Change. J. Clim. 1991, 4, 957-988. [CrossRef]

27. Tinker, P.B.; Ingram, J.S.I.; Struwe, S. Effects of Slash-and-Burn Agriculture and Deforestation on Climate Change. Agric. Ecosyst. Environ. 1996, 58, 13-22. [CrossRef]

28. Pérez-Hoyos, A.; García-Haro, F.J.; San-Miguel-Ayanz, J. Conventional and Fuzzy Comparisons of Large Scale Land Cover Products: Application to CORINE, GLC2000, MODIS and GlobCover in Europe. ISPRS J. Photogramm. Remote Sens. 2012, 74, 185-201. [CrossRef]

29. Latham, J.; Cumani, R.; Rosati, I.; Bloise, M. FAO Global Land Cover (GLC-SHARE) Beta-Release 1.0 Database. Land and Water Division; FAO: Rome, Italy, 2014.

30. Bai, Y.; Ochuodho, T.O.; Yang, J. Impact of Land Use and Climate Change on Water-Related Ecosystem Services in Kentucky, USA. Ecol. Indic. 2019, 102, 51-64. [CrossRef]

31. Kindu, M.; Schneider, T.; Teketay, D.; Knoke, T. Changes of Ecosystem Service Values in Response to Land Use/Land Cover Dynamics in Munessa-Shashemene Landscape of the Ethiopian Highlands. Sci. Total Environ. 2016, 547, 137-147. [CrossRef] [PubMed]

32. Coppin, P.; Jonckheere, I.; Nackaerts, K.; Muys, B.; Lambin, E. Digital Change Detection Methods in Ecosystem Monitoring: A Review. Int. J. Remote Sens. 2004, 25, 1565-1596. [CrossRef]

33. Letsoin, S.M.A.; Herak, D.; Rahmawan, F.; Purwestri, R.C. Land Cover Changes from 1990 to 2019 in Papua, Indonesia: Results of the Remote Sensing Imagery. Sustainability 2020, 12, 6623. [CrossRef]

34. Quintas-Soriano, C.; Castro, A.J.; Castro, H.; García-Llorente, M. Impacts of Land Use Change on Ecosystem Services and Implications for Human Well-Being in Spanish Drylands. Land Use Policy 2016, 54, 534-548. [CrossRef]

35. Ureta, J.C.; Clay, L.; Motallebi, M.; Ureta, J. Quantifying the Landscape's Ecological Benefits-An Analysis of the Effect of Land Cover Change on Ecosystem Services. Land 2021, 10, 21. [CrossRef]

36. Krkoška lorencová, E.; Harmáčková, Z.V.; Landová, L.; Pártl, A.; Vačkář, D. Assessing Impact of Land Use and Climate Change on Regulating Ecosystem Services in the Czech Republic. Ecosyst. Health Sustain. 2016, 2, e01210. [CrossRef]

37. Baskent, E.Z. A Framework for Characterizing and Regulating Ecosystem Services in a Management Planning Context. Forests 2020, 11, 102. [CrossRef]

38. Hubelova, D.; Mala, J.; Kozumplikova, A.; Schrimpelova, K.; Hornova, H.; Janal, P. Influence of Human Activity on Surface Water Quality in Moravian Karst. Pol. J. Environ. Stud. 2020, 29, 3153-3162. [CrossRef]

39. Aguilar, F.X.; Obeng, E.A.; Cai, Z. Water Quality Improvements Elicit Consistent Willingness-to-Pay for the Enhancement of Forested Watershed Ecosystem Services. Ecosyst. Serv. 2018, 30, 158-171. [CrossRef]

40. Bartram, J.; Thyssen, N.; Pond, K.; Lack, T.; European Environment Agency; World Health Organization; Gowers, A. (Eds.) Water and Health in Europe: A Joint Report from the European Environment Agency and the WHO Regional Office for Europe; WHO Regional Publications; World Health Organization: Copenhagen, Denmark, 2002; ISBN 978-92-890-1360-4.

41. Shukla, R.; Gupta, D.; Singh, G.; Mishra, V.K. Performance of Horizontal Flow Constructed Wetland for Secondary Treatment of Domestic Wastewater in a Remote Tribal Area of Central India. Sustain. Environ. Res. 2021, 31, 13. [CrossRef]

42. Bondad-Reantaso, M.G.; Arthur, J.R.; Subasinghe, R.P. (Eds.) Understanding and Applying Risk Analysis in Aquaculture; FAO fisheries and aquaculture technical paper; Food and Agriculture Organization of the United Nations: Rome, Italy, 2008; ISBN 978-92-5-106152-7.

43. OECD. Financing Water Supply, Sanitation and Flood Protection: Challenges in EU Member States and Policy Options; OECD Studies on Water; OECD: Paris, France, 2020; ISBN 978-92-64-67888-0.

44. Sochacki, A.; Marsik, P.; Chen, Z.; Sisa, M.; Vymazal, J. Fate of Antifungal Drugs Climbazole and Fluconazole in Constructed Wetlands-Diastereoselective Transformation Indicates Process Conditions. Chem. Eng. J. 2021, 421, 127783. [CrossRef]

45. Vymazal, J. Constructed Wetlands for Wastewater Treatment. Water 2010, 2, 530-549. [CrossRef]

46. Mala, J.; Schrimpelova, K.; Tuma, A.; Bilkova, Z.; Hrich, K. Assessment of river water quality in the Moravian Karst, Czech Republic. In Proceedings of the International Multidisciplinary Scientific GeoConference SGEM, Albena, Bulgaria, 29 June-5 July 2017; pp. 81-88. [CrossRef]

47. Judová, P.; Janský, B. Water Quality in Rural Areas of the Czech Republic: Key Study Slapanka River Catchment. Limnologica 2005, 35, 160-168. [CrossRef]

48. Janosova, B.; Miklankova, J.; Hlavinek, P.; Wintgens, T. Drivers for Wastewater Reuse: Regional Analysis in the Czech Republic. Desalination 2006, 187, 103-114. [CrossRef]

49. Langhammer, J. Water Quality Changes in the Elbe River Basin, Czech Republic, in the Context of the Post-Socialist Economic Transition. GeoJournal 2010, 75, 185-198. [CrossRef] 
50. Deng, J.; Qiang, S.; Walker, G.J.; Zhang, Y. Assessment on and Perception of Visitors' Environmental Impacts of Nature Tourism: A Case Study of Zhangjiajie National Forest Park, China. J. Sustain. Tour. 2003, 11, 529-548. [CrossRef]

51. Gebrehiwot, S.G.; Taye, A.; Bishop, K. Forest Cover and Stream Flow in a Headwater of the Blue Nile: Complementing Observational Data Analysis with Community Perception. AMBIO 2010, 39, 284-294. [CrossRef] [PubMed]

52. Gebrehiwot, S.G.; Bewket, W.; Bishop, K. Community Perceptions of Forest-Water Relationships in the Blue Nile Basin of Ethiopia. GeoJournal 2014, 79, 605-618. [CrossRef]

53. Petch, J.R.; Kolejka, J. The tradition of landscape ecology in Czechoslovakia. In Landscape Ecology And Geographical Information Systems; CRC Press: Boca Raton, FL, USA, 2003; pp. 41-58. ISBN 978-0-203-39303-1.

54. Van Rompaey, A.; Krasa, J.; Dostal, T. Modelling the Impact of Land Cover Changes in the Czech Republic on Sediment Delivery. Land Use Policy 2007, 24, 576-583. [CrossRef]

55. Kupková, L.; Bičík, I.; Najman, J. Land Cover Changes along the Iron Curtain 1990-2006. Geografie 2013, 118, 95-115. [CrossRef]

56. Vojtěch, A.; Oušková, V.; Kuneš, P. Present-Day Vegetation Helps Quantifying Past Land Cover in Selected Regions of the Czech Republic. PLoS ONE 2014, 9, e100117. [CrossRef]

57. Homolac, L.; Tomsik, K. Historical Development of Land Ownership in the Czech Republic since the Foundation of the Czechoslovakia until Present. Agric. Econ. Zemědělská Ekon. 2016, 62, 528-536. [CrossRef]

58. Guo, Z.; Xiao, X.; Li, D. An Assessment of Ecosystem Services: Water Flow Regulation and Hydroelectric Power Production. Ecol. Appl. 2000, 10, 925-936. [CrossRef]

59. Li, P.; Omani, N.; Chaubey, I.; Wei, X. Evaluation of Drought Implications on Ecosystem Services: Freshwater Provisioning and Food Provisioning in the Upper Mississippi River Basin. Int. J. Environ. Res. Public. Health 2017, 14, 496. [CrossRef]

60. Joint Research Centre; European Commission; Ivits, E.; Ballabio, C.; Vogt, P.; Christiansen, T.; Rega, C.; Del Barrio Alvarellos, I.; Gervasini, E.; de Roo, A.; et al. Mapping and Assessment of Ecosystems and Their Services: An EU Wide Ecosystem Assessment in Support of the EU Biodiversity Strategy; Publications Office of the European Union: Luxembourg, 2020; ISBN 978-92-76-17833-0.

61. Gretchen, C.; Dayli, S.; Ehrlich, P.; Goulder, L.; Lubchenco, J.; Matson, P.; Mooney, H.; Postel, S.; Schneider, S.; Tilman, D.; et al. Ecosystem Services: Benefits Supplied to Human Societies by Natural Ecosystems. Issues Ecol. 1997, 2, 1-16.

62. European Commission; Statistical Office of the European Union. Accounting for Ecosystems and Their Services in the European Union (INCA): Final Report from Phase II of the INCA Project Aiming to Develop a Pilot for an Integrated System of Ecosystem Accounts for the EU: 2021 Edition; Publications Office: Luxembourg, 2020.

63. Frélichová, J.; Vačkář, D.; Pártl, A.; Loučková, B.; Harmáčková, Z.V.; Lorencová, E. Integrated Assessment of Ecosystem Services in the Czech Republic. Ecosyst. Serv. 2014, 8, 110-117. [CrossRef]

64. Maes, J.; Egoh, B.; Willemen, L.; Liquete, C.; Vihervaara, P.; Schägner, J.P.; Grizzetti, B.; Drakou, E.G.; Notte, A.L.; Zulian, G.; et al. Mapping Ecosystem Services for Policy Support and Decision Making in the European Union. Ecosyst. Serv. 2012, 1, 31-39. [CrossRef]

65. Šantrůčková, M.; Demková, K.; Weber, M.; Lipský, Z.; Dostálek, J. Long Term Changes in Water Areas and Wetlands in an Intensively Farmed Landscape: A Case Study from the Czech Republic. Eur. Countrys. 2017, 9, 132-144. [CrossRef]

66. Kowalczak, P.; Maczak, P.; Slavikova, L. Institutional Evolution in Water Management in the Czech Republic and Poland. Int. J. Water Gov. 2013, 1, 307-322. [CrossRef]

67. Van Puijenbroek, P.J.T.M.; Beusen, A.H.W.; Bouwman, A.F. Global Nitrogen and Phosphorus in Urban Waste Water Based on the Shared Socio-Economic Pathways. J. Environ. Manag. 2019, 231, 446-456. [CrossRef] [PubMed]

68. OECD. Financing Water: Investing in Sustainable Growth; OECD: Paris, France, 2018. [CrossRef]

69. Alaerts, G.J. Financing for Water-Water for Financing: A Global Review of Policy and Practice. Sustainability $2019,11,821$. [CrossRef]

70. Soukopova, J.; Bakos, E. Assessing the Efficiency of Municipal Expenditures Regarding Environmental Protection. WIT Trans. Ecol. Environ. 2010, 131, 107-119.

71. OECD. Financing Water Supply, Sanitation and Flood Protection. Czech Republic Fact Sheet; OECD: Paris, France, 2020.

72. Pörtner, H.O.; Scholes, R.J.; Agard, J.; Archer, E.; Arneth, A.; Bai, X.; Barnes, D.; Burrows, M.; Chan, L.; Ngo, H.T.; et al. Scientific Outcome of the IPBES-IPCC Co-Sponsored Workshop on Biodiversity and Climate Change; IPBES secretariat: Bonn, Germany, 2021. [CrossRef]

73. Butler, J.R.A. An Analysis of Trade-Offs between Multiple Ecosystem Services and Stakeholders Linked to Land Use and Water Quality Management in the Great Barrier Reef, Australia. Agric. Ecosyst. Environ. 2013, 180, 176-191. [CrossRef]

74. Pacheco, F.A.L.; Varandas, S.G.P.; Sanches Fernandes, L.F.; Valle Junior, R.F. Soil Losses in Rural Watersheds with Environmental Land Use Conflicts. Sci. Total Environ. 2014, 485-486, 110-120. [CrossRef] [PubMed]

75. Carpenter, S.R.; Stanley, E.H.; Vander Zanden, M.J. State of the World's Freshwater Ecosystems: Physical, Chemical, and Biological Changes. Annu. Rev. Environ. Resour. 2011, 36, 75-99. [CrossRef]

76. Český Statistický Úřad. Statistical Yearbook of the Czech Republic-2020; Český Statistický Úřad: Prague, Czech Republic, 2020; ISBN 978-80-250-3050-9.

77. CENIA, Ministry of the Environment of the Czech Republic (MoE). Zpráva o Životním Prostředí Ve Středočeském Kraji 2018; Czech Environmental Information Agency: Prague, Czech Republic, 2019; p. 52. ISBN 978-80-7674-015-0.

78. CENIA, Ministry of the Environment of the Czech Republic (MoE). Zpráva o Životním Prostředi v Jihomoravském Kraji 2018; Czech Environmental Information Agency: Prague, Czech Republic, 2019; p. 52. ISBN 978-80-87770-83-2. 
79. European Environment Agency CORINE Land Cover-Copernicus Land Monitoring Service. Available online: https://land. copernicus.eu/pan-european/corine-land-cover (accessed on 18 June 2021).

80. ESRI. ArcGIS Desktop 10.8; Environmental Systems Research Institute, Inc.: West Redlands, CA, USA, 2019.

81. European Union; Copernicus Land Monitoring Service (CLMS); European Environment Agency (EEA). Copernicus Land Monitoring Service. CORINE Land Cover; Product User Manual Version 1.0; European Union; Copernicus Land Monitoring Service; European Environment Agency: Copenhagener, Denmark, 2021.

82. Ministry of Agriculture of the Czech Republic (MoA). Zpráva o Stavu Lesa a Lesního Hospodářství České Republiky v Roce 1998; Ministerstvo zemědělství (Ministry of Agriculture the Czech Republic): Prague, Czech Republic, 1999; p. 138.

83. Ministry of Agriculture of the Czech Republic (MoA). Zpráva o Stavu Lesa a Lesního Hospodářství České Republiky v Roce 2019; Department of Agriculture: Prague, Czech Republic, 2020; p. 114. ISBN 9788074345302.

84. Czech Statistical Office Statistics. Available online: https:/ / www.czso.cz/csu/czso/statistics (accessed on 19 June 2021).

85. European Commission. Evaluation of the Urban Waste Water Treatment Directive; European Commission: Brussels, Belgium, 2019; p. 186.

86. European Commission; Berland, J.M.; Xavier, L.D.; Neumann, T.; Madec, C.; Dhuygelaere, N.; Fribourg-blanc, B.; Hocquet, C. 10th Technical Assessment on the Urban Waste Water Treatment Directive (UWWTD) Implementation 2016 European Review and National Situation: Final Version; Publications Office of the European Union: Luxembourg, 2020; ISBN 978-92-76-20423-7.

87. OECD. Recommendation of the Council on the Use of Economic Instruments in Environmental Policy, OECD/LEGAL/0258; OECD Legal Instruments: Paris, France, 2021; ISBN 978-92-76-20423-7.

88. United Nations. Guía metodológica: Instrumentos Económicos para la Gestión Ambiental; Pantaleón, C., Pereira, M., de Miguel, C., Eds.; Comisión Económica para América Latina y el Caribe (CEPAL): Santiago de Chile, Chile, 2015.

89. OECD. Policy Instruments for the Environment. Database Documentation; OECD: Paris, France, 2016.

90. European Commission; Statistical Office of the European Union. Environmental Protection Expenditure Accounts: Handbook 2017 Edition; Publications Office: Luxembourg, 2017; ISBN 978-92-79-66261-4.

91. Ministry of Agriculture of the Czech Republic (MoA); Ministry of the Environment of the Czech Republic (MoE). Report on Water Management in the Czech Republic in 2019; Department of State Administration of Water Management and River Basins: Prague, Czech Republic, 2020; ISBN 978-80-7434-511-1.

92. Czech National Bank. Financial Market Inflation Expectations—December 2019; Czech National Bank: Prague, Czech Republic, 2019.

93. Czech Statistical Office (CZSO) Environmental Accounts. Available online: https://www.czso.cz/csu/czso/environmentalaccounts (accessed on 10 June 2021).

94. Ryzin, G.G.V. Expectations, Performance, and Citizen Satisfaction with Urban Services. J. Policy Anal. Manag. 2004, 23, 433-448. [CrossRef]

95. European Commission; Eurostat. GISCO Nomenclature of Territorial Units for Statistics (NUTS) 2021-Statistical Units—Data Set 2020; European Commission: Luxembourg, 2020.

96. Martínez, M.L.; Pérez-Maqueo, O.; Vázquez, G.; Castillo-Campos, G.; García-Franco, J.; Mehltreter, K.; Equihua, M.; Landgrave, R. Effects of Land Use Change on Biodiversity and Ecosystem Services in Tropical Montane Cloud Forests of Mexico. For. Ecol. Manag. 2009, 258, 1856-1863. [CrossRef]

97. Perdana, M.C.; Hadisusanto, S.; Purnama, I.L.S. Implementation of a Full-Scale Constructed Wetland to Treat Greywater from Tourism in Suluban Uluwatu Beach, Bali, Indonesia. Heliyon 2020, 6, e05038. [CrossRef]

98. Ministry of Agriculture of the Czech Republic (MoA). Zpráva o Stavu Lesa a Lesního Hospodářství České Republiky v Roce 2018; Ministerstvo zemědělství (Ministry of Agriculture the Czech Republic): Prague, Czech Republic, 2019; p. 114.

99. Food and Agriculture Organization of the United Nations (FAO). Global Forest Resources Assessment 2015: Desk Reference. Rome. 2017. Available online: http:/ /www.fao.org/forest-resources-assessment/past-assessments/fra-2015/en/ (accessed on 9 August 2019).

100. Purwestri, R.C.; Hájek, M.; Šodková, M.; Sane, M.; Kašpar, J. Bioeconomy in the National Forest Strategy: A Comparison Study in Germany and the Czech Republic. Forests 2020, 11, 608. [CrossRef]

101. Ministry of Agriculture of the Czech Republic (MoA). Zpráva o Stavu Lesa a Lesního Hospodářství České Republiky v Roce 2018-Vládní verze; Ministerstvo zemědělství (Ministry of Agriculture the Czech Republic): Prague, Czech Republic, 2019 ; p. 41.

102. Ministry of Agriculture. Water Information System of the Czech Republic. Guide to Applications; Department of State Administration of Water Management and River Basin: Prague, Czech Republic, 2008; ISBN 978-80-7084-739-8.

103. Ministry of Agriculture of the Czech Republic (MoA). Zpráva o Stavu Lesa a Lesního Hospodárství České Republiky v Roce 2012; Ministerstvo zemědělství (Ministry of Agriculture the Czech Republic): Prague, Czech Republic, 2013; p. 135.

104. Ministry of Agriculture of the Czech Republic (MoA). Zpráva o Stavu Lesa a Lesního Hospodářství České Republiky v Roce 2006; Ministerstvo zemědělství (Ministry of Agriculture the Czech Republic): Prague, Czech Republic, 2007; p. 59.

105. Janík, T.; Romportl, D. Recent Land Cover Change after the Kyrill Windstorm in the Šumava NP. Appl. Geogr. 2018, 97, 196-211. [CrossRef]

106. Czech Statistical Office (CZSO); Moravec, Š. Kde a Jak Bydli České Domácnosti? Population Statistics Department: Prague, Czech Republic, 2011; p. 36.

107. Czech Government. Act No. 289/1995 Coll., on Forests and Amendments to Some Legal Regulations (Forest Act); Parliament of the Czech Republic: Prague, Czech Republic, 1995; p. 50. 
108. Vancura, K. National Forestry Programme of the Czech Republic in Brief. J. For. Sci. 2004, 50, 500-504. [CrossRef]

109. Urbanová, M. The National Forest Programme of the Czech Republic: An Introduction of the 1993-2010 Development. Acta Univ. Agric. Silvic. Mendel. Brun. 2014, 59, 185-192. [CrossRef]

110. European Commission. New EU Forest Strategy for 2030; European Commission: Brussels, Belgium, 2021.

111. Ministry of Agriculture of the Czech Republic (MoA); Ministry of the Environment of the Czech Republic (MoE). Zpráva o Stavu Vodního Hospodářství České Republiky v Roce 2018; Department of Agriculture: Prague, Czech Republic, 2019; p. 142. ISBN 978-80-7434-523-4.

112. Cudmore, T.J.; Björklund, N.; Carroll, A.L.; Lindgren, B.S. Climate Change and Range Expansion of an Aggressive Bark Beetle: Evidence of Higher Beetle Reproduction in Naïve Host Tree Populations. J. Appl. Ecol. 2010, 47, 1036-1043. [CrossRef]

113. Holusa, J.; Lubojacky, J.; Knizek, M. Distribution of the Double-Spined Spruce Bark Beetle Ips Duplicatus in the Czech Republic: Spreading in 1997-2009. Phytoparasitica 2010, 38, 435-443. [CrossRef]

114. Davídková, M.; Doležal, P. Temperature-Dependent Development of the Double-Spined Spruce Bark Beetle Ips Duplicatus (Sahlberg, 1836) (Coleoptera; Curculionidae). Agric. For. Entomol. 2019, 21, 388-395. [CrossRef]

115. Hlásny, T.; Zimová, S.; Merganičová, K.; Štěpánek, P.; Modlinger, R.; Turčáni, M. Devastating Outbreak of Bark Beetles in the Czech Republic: Drivers, Impacts, and Management Implications. For. Ecol. Manag. 2021, 490, 119075. [CrossRef]

116. Purwestri, R.C.; Hájek, M.; Šodková, M.; Jarský, V. How Are Wood and Non-Wood Forest Products Utilized in the Czech Republic? A Preliminary Assessment of a Nationwide Survey on the Bioeconomy. Sustainability 2020, 12, 566. [CrossRef]

117. FAO. Towards a Water and Food Secure Future: Critical Perspectives for Policy-Makers; FAO \& WWC: Rome, Italy, 2015.

118. CDP Worldwide. CDP Global Water Report 2018. Treading Water: Corporate Responses to Rising Water Challenges; CDP Worldwide: London, UK, 2018; p. 84.

119. Pittock, J.; Hansen, L.J.; Abell, R. Running Dry: Freshwater Biodiversity, Protected Areas and Climate Change. Biodiversity 2008, 9 , 30-38. [CrossRef]

120. Neary, D.G.; Ice, G.G.; Jackson, C.R. Linkages between Forest Soils and Water Quality and Quantity. For. Ecol. Manag. 2009, 258, 2269-2281. [CrossRef]

121. Lopes, A.F.; Macdonald, J.L.; Quinteiro, P.; Arroja, L.; Carvalho-Santos, C.; Cunha-e-Sá, M.A.; Dias, A.C. Surface vs. Groundwater: The Effect of Forest Cover on the Costs of Drinking Water. Water Resour. Econ. 2019, 28, 100123. [CrossRef]

122. Pérez-Suárez, M.; Arredondo-Moreno, J.; Huber-Sannwald, E.; Serna-Pérez, A. Forest Structure, Species Traits and Rain Characteristics Influences on Horizontal and Vertical Rainfall Partitioning in a Semiarid Pine-Oak Forest from Central Mexico. Ecohydrology 2014, 7, 532-543. [CrossRef]

123. Stolton, S.; Dudley, N. Managing Forests for Cleaner Water for Urban Populations. Unasylva 2007, 58, 5.

124. Vodouhê, F.G.; Coulibaly, O.; Adégbidi, A.; Sinsin, B. Community Perception of Biodiversity Conservation within Protected Areas in Benin. For. Policy Econ. 2010, 12, 505-512. [CrossRef]

125. Dasgupta, M.; Yildiz, Y. Assessment of Biochemical Oxygen Demand as Indicator of Organic Load in Wastewaters of Morris County, New Jersey, USA. J. Environ. Anal. Toxicol. 2016, 6, 378. [CrossRef]

126. Kolb, M.; Bahadir, M.; Teichgräber, B. Determination of Chemical Oxygen Demand (COD) Using an Alternative Wet Chemical Method Free of Mercury and Dichromate. Water Res. 2017, 122, 645-654. [CrossRef] [PubMed]

127. Dodds, W.K.; Smith, V.H. Nitrogen, Phosphorus, and Eutrophication in Streams. Inland Waters 2016, 6, 155-164. [CrossRef]

128. Leoni, B.; Patelli, M.; Soler, V.; Nava, V. Ammonium Transformation in 14 Lakes along a Trophic Gradient. Water 2018, 10, 265. [CrossRef]

129. Zeng, Q.; Qin, L.; Bao, L.; Li, Y.; Li, X. Critical Nutrient Thresholds Needed to Control Eutrophication and Synergistic Interactions between Phosphorus and Different Nitrogen Sources. Environ. Sci. Pollut. Res. 2016, 23, 21008-21019. [CrossRef]

130. Aguilar-Ascon, E. Removal of Nitrogen and Phosphorus from Domestic Wastewater by Electrocoagulation: Application of Multilevel Factorial Design. J. Ecol. Eng. 2020, 21, 124-133. [CrossRef]

131. Richards, S.; Paterson, E.; Withers, P.J.A.; Stutter, M. The Contribution of Household Chemicals to Environmental Discharges via Effluents: Combining Chemical and Behavioural Data. J. Environ. Manag. 2015, 150, 427-434. [CrossRef] [PubMed]

132. Stabenau, N.; Zehnsdorf, A.; Rönicke, H.; Wedwitschka, H.; Moeller, L.; Ibrahim, B.; Stinner, W. A Potential Phosphorous Fertilizer for Organic Farming: Recovery of Phosphorous Resources in the Course of Bioenergy Production through Anaerobic Digestion of Aquatic Macrophytes. Energy Sustain. Soc. 2018, 8, 16. [CrossRef]

133. Fitobór, K.; Quant, B. Is the Microfiltration Process Suitable as a Method of Removing Suspended Solids from Rainwater? Resources 2021, 10, 21. [CrossRef]

134. Koda, E.; Miszkowska, A.; Podlasek, A. Levels of Organic Pollution Indicators in Groundwater at the Old Landfill and Waste Management Site. Appl. Sci. 2017, 7, 638. [CrossRef]

135. Vaishar, A.; Jakešová, L.; Náplavová, M. Current Problems in the South-Moravian Rural Landscape. Eur. Countrys. 2012, 3 , 265-281. [CrossRef]

136. Ministry of Agriculture of the Czech Republic (MoA); Ministry of the Environment of the Czech Republic (MoE). Report on Water Management in the Czech Republic in 2009; Department of State Administration of Water Management and River Basins: Prague, Czech Republic, 2010.

137. Giokas, D.; Vlessidis, A.; Angelidis, M.; Tsimarakis, G.; Karayannis, M. Systematic Analysis of the Operational Response of Activated Sludge Process to Variable Wastewater Flows. A Case Study. Clean Technol. Environ. Policy 2002, 4, 183-190. [CrossRef] 
138. Bersinger, T.; Le Hécho, I.; Bareille, G.; Pigot, T. Assessment of Erosion and Sedimentation Dynamic in a Combined Sewer Network Using Online Turbidity Monitoring. Water Sci. Technol. 2015, 72, 1375-1382. [CrossRef] [PubMed]

139. Czech Environmental Information Agency. Report on the Environment of the Czech Republic in 2016; Czech Environmental Information Agency: Prague, Czech Republic, 2017; p. 219.

140. Nelson, N.; Mikkelsen, R. Meeting the Phosphorus Requirement on Organic Farms. Better Crops 2008, 92, 12-14.

141. CENIA, Ministry of the Environment of the Czech Republic (MoE). Souhrnná Zpráva o Životním Prostředí v Krajích ČR.; Czech Czech Environmental Information Agency: Prague, Czech Republic, 2021; p. 51. ISBN 978-80-7674-014-3.

142. Soukopová, J.; Struk, M. Methodology for the Efficiency Evaluation of the Municipal Environmental Protection Expenditure. In Proceedings of the Environmental Software Systems. Frameworks of Environment, Brno, Czech Republic, 27-29 June 2011; Hřebiček, J., Schimak, G., Denzer, R., Eds.; Springer: Berlin/Heidelberg, Germany, 2011; pp. 327-340.

143. Baun, M.J.; Marek, D. Implementing EU Environmental Law in the New Member States: The Urban Waste Water Treatment Directive in the Czech Republic. Contemp. Eur. Stud. 2013, 1, 5-25.

144. Krajewski, P. The Impact of Public Environmental Protection Expenditure on Economic Growth. Probl. Ekorozw. Probl. Sustain. Dev. 2016, 11, 99-104.

145. European Commission. Natural Capital Accounting: Overview and Progress in the European Union; Publications Office of the European Union: Luxembourg, 2019; p. 80. 